\title{
African Sorghum-Based Fermented Foods: Past, Current and Future Prospects
}

\author{
Oluwafemi Ayodeji Adebo \\ Department of Biotechnology and Food Technology, Faculty of Science, University of \\ Johannesburg (Doornfontein Campus), P.O. Box 17011 Johannesburg, Gauteng 2028, South Africa; \\ oadebo@uj.ac.za; Tel.: +27-11-559-6261
}

Received: 28 February 2020; Accepted: 14 April 2020; Published: 16 April 2020

check for updates

\begin{abstract}
Sorghum (Sorghum bicolor) is a well-known drought and climate resistant crop with vast food use for the inhabitants of Africa and other developing countries. The importance of this crop is well reflected in its embedded benefits and use as a staple food, with fermentation playing a significant role in transforming this crop into an edible form. Although the majority of these fermented food products evolve from ethnic groups and rural communities, industrialization and the application of improved food processing techniques have led to the commercial success and viability of derived products. While some of these sorghum-based fermented food products still continue to bask in this success, much more still needs to be done to further explore evolving techniques, technologies and processes. The addition of other affordable nutrient sources in sorghum-based fermented foods is equally important, as this will effectively augment the intake of a nutritionally balanced product.
\end{abstract}

Keywords: sorghum; fermentation; lactic acid bacteria; fermented products; food security; 4th industrial revolution (4IR)

\section{Introduction}

In terms of production quantity, sorghum is the fifth most important cereal crop in the world after rice, wheat, maize and barley, and the most grown cereal in Sub-Saharan Africa, after maize [1-3]. It remains one of the most versatile cereal crops on the continent, serving as a staple and main meal for millions of people $[1,3,4]$. It is an important source of calories, variety of nutrients and beneficial food components [5-7]. With the increasing world population, decrease in water supply and the effects of climate change, this drought resistant food crop is vital for human utilization and will be an important crop for the future.

Amongst all the available food processing techniques, fermentation is an age-long process, known to improve nutritional qualities, palatability and consumer appeal [8-11]. Derived fermented food products continue to constitute an important part of our daily diet and are estimated to provide about a third of world food supplies [12]. These foods are known to confer beneficial effects, including therapeutic and functional properties, in addition to possessing antimicrobial, antioxidant, probiotic and cholesterol-lowering attributes, and are a source of some other important bioactive compounds [11,13-17]. Accordingly, fermented sorghum-based foods have a long history and strong cultural ties to the African people in particular.

Although sorghum is the third most produced cereal grain in Africa after maize and rice, it has not been fully utilized for industrial processing as compared to other major cereals. Rapid urbanization, an increasing population, the cost of other imported cereal commodities and the demand for high quality functional foods have nonetheless driven the rise in the consumption of sorghum-based food products. Further to this, the demand for gluten-free foods for people with celiac disease and other intolerances to wheatpositions sorghum as a suitable substrate for these types of diet. There is also an upsurge 
and renewed interest in the use of alternative, climate-smart and traditional grains, like sorghum, in modern food products [18]. Particularly important is the vital role that sorghum plays as one of the main sources of food and energy, similarly to other cereals. This review describes sorghum-based fermented foods, highlighting notable traditionally processed products that have become a commercial success. Prospects for the future and possibilities of areas that should be explored are also emphasized.

\section{Overview on Sorghum}

Judging from the 2017 available data from FAOSTAT, Africa is the largest contributor to world sorghum production, with a production quantity of approximately 29.7 million tonnes [1]. Sorghum grains are a widely adaptable species and mostly cultivated in tropical, subtropical and temperate regions [19]. As a drought tolerant and a climate-smart crop under the prevailing realities of climate change, its utilization is spread across diverse industries, including for animal feed, biofuels, forage, ethanol production and fodder preservation [20,21]. It remains one of the most versatile food crops in Africa.

Sorghum belongs to the Andropogoneae tribe and Poaceae family and is a known $\mathrm{C}_{4}$ crop (i.e., it uses the $\mathrm{C}_{4}$ carbon fixation pathway to increase its photosynthetic efficiency), particularly adapted to hot, drought-prone and semi-arid tropical environments with less rainfall. It is said to have originated from the Northeast quadrant of Africa [22]. Millet, barley, teff and wheat are also members of the Poaceae family [23] and are likewise known for their ecological dominance in many ecosystems, as well as their capacity to grow in low rainfall and harsh environmental extremes conditions [24]. As indicated by Ratnavathi and Komala [25], over 20 sorghum species are known and these include: Sorghum almum, Sorghum amplum, Sorghum angustum, Sorghum arundinaceum, Sorghum bicolor, Sorghum brachypodum, Sorghum bulbosum, Sorghum burmahicum, Sorghum ecarinatum, Sorghum exstans, Sorghum grande, Sorghum halepense, Sorghum interjectum, Sorghum intrans, Sorghum laxiflorum, Sorghum leiocladum, Sorghum macrospermum, Sorghum matarankense, Sorghum nitidum, Sorghum plumosum, Sorghum propinquum, Sorghum purpureosericeum, Sorghum stipoideum, Sorghum timorense, Sorghum trichocladum, Sorghum versicolor, Sorghum verticiliflorum and Sorghum vulgare var. technicum. Notable among these is S. bicolor, known for its food use.

Sorghum grains are single seeded, with their pericarp surrounding and tight adherence to the seed coat $[6,26]$. Its grass varies between 0 and $6 \mathrm{~m}$ in height, with deep, spreading roots and a solid stem. Sorghum kernels are usually flattened spheres measuring about 4, 2.5 and $3.5 \mathrm{~mm}$ in length, thickness and width, respectively, with an average weight of about $25 \mathrm{mg}$ [26]. Sorghum grains can typically be white, pale orange, tan, red, dark brown and brownish-red [5,26,27], but the major commercially available ones are the black, white and red (Figure 1). The color of the testa (seed coat or pericarp) are genetic characters controlled by the $\mathrm{R}$ and $\mathrm{Y}$ genes $[22,28]$.

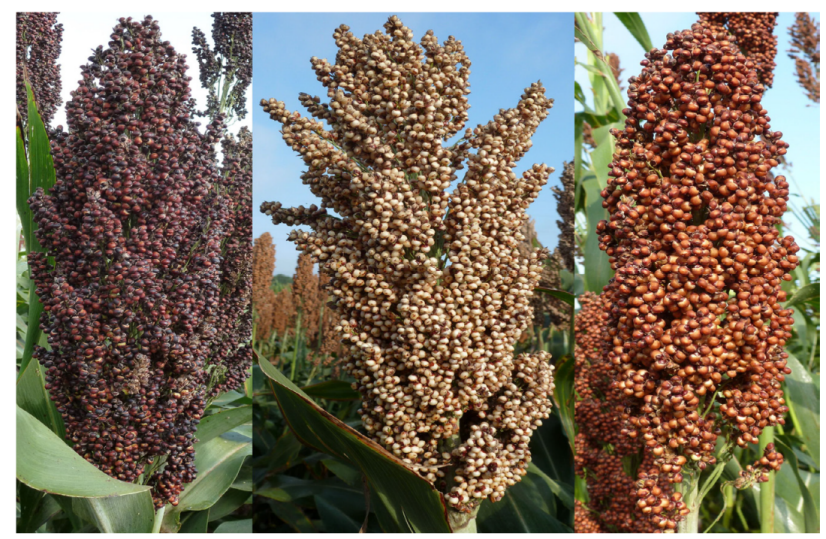

Figure 1. Mature panicles of different types of sorghum in the field. Black (left), white (middle), and red (right) sorghum (Adapted from Awika [27]). 


\subsection{Nutitional Composition of Sorghum}

In developing countries, especially in Africa, over $78 \%$ of the sorghum produced is used for food, with about $14 \%$ for animal feeding and 7\% for other uses [29]. Extensive studies on the composition of sorghum have indicated that the grain is a good source of energy, carbohydrates, polyunsaturated fatty acids (PUFAs), minerals, vitamins and some essential amino acids $[27,28,30]$. Proximate composition of sorghum from earlier studies has indicated that its protein content ranges from $6.2 \%$ to $14.9 \%$, carbohydrates $(54.6 \%-85.2 \%)$, fat $(1.3 \%-10.5 \%)$, ash $(0.9 \%-4.2 \%)$ and fibre $(1.4 \%-26.1 \%)$ (Table 1$)$. The variations in these values might possibly be related to the genotypes of the grains and growth conditions, as well as other cultivar specific differences. As indicated by previous authors [27,31], starch, including dietary fiber derived from cellulosic cell wall carbohydrates, is a major component of sorghum, constituting about $75 \%$ of the grain. The presence of non-starch polysaccharides (NSPs) in sorghum grains could be suggestive of their potential ability to improve bowel function and lower cholesterol levels [32,33]. 
Table 1. Proximate composition of sorghum.

\begin{tabular}{|c|c|c|c|c|c|c|c|c|c|c|c|c|}
\hline $\begin{array}{c}\text { Proximate } \\
\text { Composition (\%) }\end{array}$ & $\begin{array}{c}\text { Jones and } \\
\text { Beckwith [34] }\end{array}$ & $\begin{array}{c}\text { Okoh } \\
\text { et al. [35] }\end{array}$ & $\begin{array}{c}\text { Adebiyi et al. } \\
\text { [36] }\end{array}$ & $\begin{array}{l}\text { Shawrang } \\
\text { et al. [37] }\end{array}$ & $\begin{array}{c}\text { Shargie } \\
{[38]}\end{array}$ & $\begin{array}{l}\text { Udachan } \\
\text { et al. [39] }\end{array}$ & $\begin{array}{c}\text { Awadelkareem } \\
\text { et al. [40] }\end{array}$ & $\begin{array}{l}\text { Ndimba } \\
\text { et al. [41] }\end{array}$ & $\begin{array}{l}\text { Singh } \\
\text { et al. [42] }\end{array}$ & $\begin{array}{c}\text { Ape et al. } \\
{[43]}\end{array}$ & $\begin{array}{c}\text { Jimoh and } \\
\text { Abdullahi [44] }\end{array}$ & $\begin{array}{r}\text { Mohapatra } \\
\text { et al. [45] }\end{array}$ \\
\hline Ash & $1.2-1.3$ & $0.90-1.52$ & 1.98 & 4.20 & 1.44 & $0.92-1.75$ & $1.28-1.78$ & $1.61-2.03$ & 1.90 & 2.07 & $1.12-1.68$ & 3.17 \\
\hline $\mathrm{CHO}$ & NR & $71.80-85.20$ & 72.41 & NR & NR & $70.65-76.20$ & $72.44-77.28$ & NR & NR & 76.51 & $65.15-76.28$ & 71.95 \\
\hline Fat & $3.1-3.4$ & $1.38-4.50$ & 3.35 & 6.9 & 3.32 & $2.30-2.80$ & $2.84-3.02$ & $2.37-2.75$ & 3.30 & 3.10 & $5.12-10.54$ & 4.70 \\
\hline Fiber & $1.8-1.9$ & $1.47-2.45$ & 2.25 & 19.5 & 1.83 & $1.40-2.70$ & $1.72-2.02$ & NR & 1.7 & 2.86 & $1.65-7.94$ & 2.76 \\
\hline Moisture & NR & NR & 10.66 & $8.1-8.5$ & NR & $8.10-9.99$ & $6.67-7.29$ & $8.95-11.16$ & 9.80 & 6.36 & $1.39-19.02$ & 6.07 \\
\hline Protein & $11.5-11.7$ & $9.28-14.86$ & 9.35 & 11.80 & 9.95 & $8.90-11.02$ & $10.21-13.45$ & $11.90-12.82$ & 12.5 & 9.10 & $6.23-13.81$ & 11.36 \\
\hline
\end{tabular}

$\mathrm{CHO}$ - carbohydrate; NR - not reported. Values are expressed in dry matter. 
Sorghum contains both some of the essential and non-essential amino acids, including alanine (7.34-9.62 g/100 g), aspartic acid (4.83-7.06 g/100 g), glutamic acid (17.5-28.12 g/100 g), leucine (12.02-14.48 g/100 g), phenyalanine (4.03-5.62 g/100 g), proline (6.66-12.34 g/100 g) and valine (4.22-6.86 g/100 g) (Table 2), but limited in lysine and tryptophan. It does, however, have beneficial bioactive peptides and protein fractions, including 2-kDa antiviral peptide, $\alpha$-kafirin, karifin, protease, amylase and xylanase inhibitors, as well as cationic peroxidase, which exerts anticancer, antiviral, antioxidant, cholesterol-lowering and antihypertensive effects [46-49].

Available studies have also indicated that sorghum contain minerals (Table 3) and vitamins (Table 4), both of which constitute part the essential nutrients required by humans to perform the functions necessary to sustain life. Sorghum contains fairly high levels of potassium (K) (900-6957.67 mg/kg), and phosphorus $(\mathrm{P})(1498-3787.25 \mathrm{mg} / \mathrm{kg})$, minerals known to assist with muscle movement, keeping the nervous system healthy and building strong bones and teeth. Vital vitamins reported in sorghum also include the B-vitamins (0.1-19.9 mg/100 g), vitamin E ( $1.38 \mathrm{mg} / 100 \mathrm{~g})$. Trace amounts (maximum of $0.01 \mathrm{mg} / 100 \mathrm{~g}$ ) of $\beta$-carotene (a vitamin and precursor of vitamin $A$ ) have also been reported [50,51], an indication that sorghum cannot be considered a good source of $\beta$-carotene and vitamin $A$. Considering the nutrient deficiencies in under-developed and developing countries in Africa, the limitation of some of these vital nutrients could be addressed by complementing sorghum with legumes (a plant source), as well as animal products. This will contribute to ensuring a nutritional balance of these nutrients, and assist in alleviating and counteracting micronutrient deficiencies. 
Table 2. Amino acid composition (g/100 g) of sorghum.

\begin{tabular}{|c|c|c|c|c|c|c|c|c|c|c|c|c|c|c|c|c|c|c|}
\hline Reference & Ala & Arg & Asp & Cys & Glu & Gly & His & Ile & Leu & Lys & Met & Phe & Pro & Ser & Thr & $\operatorname{Trp}$ & Tyr & Val \\
\hline $\begin{array}{l}\text { Awadelkareem } \\
\text { et al. [40] }\end{array}$ & $8.69-8.70$ & $2.79-3.61$ & $4.83-5.28$ & NR & $17.50-19.57$ & $2.36-3.08$ & $1.75-1.77$ & $3.61-3.72$ & $12.48-13.48$ & $1.57-2.31$ & $1.55-1.88$ & $4.73-5.10$ & $7.70-8.16$ & $3.77-3.85$ & $2.48-2.64$ & NR & $3.72-3.75$ & $4.65-4.74$ \\
\hline Khalil et al. [50] & $9.0-9.2$ & 3.3 & $6.5-6.8$ & 1.2 & $21.6-22$ & 3.0 & $1.7-1.8$ & $4.0-4.1$ & $13.6-13.8$ & $2.5-2.6$ & $1.3-1.4$ & $5.1-5.2$ & $9.4-10.7$ & $4.3-4.4$ & 3.2 & 0.9 & $2.9-3.0$ & $4.8-4.9$ \\
\hline Salunkhe et al. [52] & $7.34-9.62$ & $3.20-4.68$ & $4.98-6.66$ & $1.94-3.06$ & $23.42-28.12$ & $3.12-4.12$ & $1.46-2.46$ & $3.92-4.86$ & $12.02-14.48$ & $1.42-2.72$ & $1.36-2.34$ & $4.03-5.62$ & $8.92-12.34$ & $3.92-5.66$ & $1.92-2.42$ & $0.49-1.16$ & $2.12-3.62$ & $5.12-6.86$ \\
\hline Afify et al. [53] & $7.43-8.83$ & $3.58-4.01$ & $6.24-7.06$ & $1.69-2.11$ & $18.45-20.63$ & $2.84-3.05$ & $1.93-2.17$ & $3.49-3.85$ & $11.74-13.56$ & $2.11-2.26$ & $2.73-2.94$ & $4.40-4.98$ & $6.66-8.99$ & $3.49-4.17$ & $2.75-3.21$ & NR & $4.22-4.33$ & $4.22-4.82$ \\
\hline
\end{tabular}

Table 3. Mineral composition (mg/kg, d.b) of sorghum.

\begin{tabular}{|c|c|c|c|c|c|c|c|c|c|c|c|c|c|c|c|c|}
\hline Reference & $\mathrm{Ca}$ & $\mathrm{Cd}$ & Co & $\mathrm{Cr}$ & $\mathrm{Cu}$ & $\mathrm{Fe}$ & I & $\mathrm{K}$ & $\mathrm{Mg}$ & Mn & $\mathrm{Na}$ & $\mathrm{Ni}$ & $\mathbf{P}$ & $\mathrm{Pb}$ & Se & $\mathrm{Zn}$ \\
\hline $\begin{array}{l}\text { Mabelele et al. } \\
\text { [54] }\end{array}$ & $100.1-121.3$ & NR & NR & NR & $1.9-2.4$ & $24.3-40.3$ & ND & $2751-3524$ & 1130-1440 & $14.2-20.2$ & $20-40$ & NR & $2210-3327$ & NR & NR & $16.2-24.2$ \\
\hline $\begin{array}{l}\text { Shegro et al. } \\
\text { [55] }\end{array}$ & $204.50-447.50$ & NR & NR & NR & NR & $41.17-127.50$ & NR & $1150-2568.75$ & NR & $9.5-23.83$ & $11.5-54.38$ & NR & $1498-3787.25$ & NR & NR & $13.5-34.67$ \\
\hline $\begin{array}{c}\text { Pontieri et al. } \\
\text { [56] }\end{array}$ & $233.84-411.83$ & $9.92-60.54$ & 7.12-15.24 & $121.59-254.18$ & NR & $39.36-77.03$ & $14.81-212.70$ & $3434.46-6957.67$ & $1454.92-2862.00$ & 8.93-19.44 & $455.09-840.69$ & $0.46-1.27$ & $2148.60-2963.40$ & $92.62-303.89$ & 2.98-14.13 & $21.10-47.05$ \\
\hline $\begin{array}{c}\text { Gerrano et al. } \\
\text { [57] }\end{array}$ & $44.57-477.04$ & NR & NR & NR & NR & $13.50-55.13$ & NR & 900-3366 & 854-1631.17 & $11.17-20.17$ & $12.50-62.03$ & NR & 2042.19-3775 & NR & NR & $12-44.83$ \\
\hline
\end{tabular}

$\mathrm{Ca}$ - calcium; Cd - cadmium; Co - cobalt; $\mathrm{Cr}$ - chromium; $\mathrm{Cu}$ - copper; Fe - iron; I - iodine; $\mathrm{K}$ - potassium; $\mathrm{Mg}$ - magnesium; Mn - manganese; Na - sodium; Ni - nickel; $\mathrm{P}$ - phosphorus; $\mathrm{Pb}$ - lead; $\mathrm{Se}$ - selenium; $\mathrm{Zn}$ - zinc. $\mathrm{NR}$ - not reported. Values are expressed in dry matter. 
Table 4. Vitamin composition (mg/100 g) of sorghum.

\begin{tabular}{cccccc}
\hline Vitamins & $\begin{array}{c}\text { Khalil et al. } \\
\text { [50] }\end{array}$ & $\begin{array}{c}\text { Serna-Saldivar and } \\
\text { Espinosa-Ramirez [58] }\end{array}$ & $\begin{array}{c}\text { Kulamarva et al. } \\
\text { [59] }\end{array}$ & $\begin{array}{c}\text { Ochanda et al. } \\
\text { [60] }\end{array}$ & $\begin{array}{c}\text { Saleh et al. } \\
\text { [61] }\end{array}$ \\
\hline $\mathbf{B}_{\mathbf{1}}$ & $0.69-0.73$ & 0.45 & $\mathrm{NR}$ & $0.34-0.35$ & 0.38 \\
$\mathbf{B}_{\mathbf{2}}$ & $0.12-0.14$ & 0.16 & 0.13 & $0.15-0.16$ & 0.15 \\
$\mathbf{B}_{\mathbf{3}}$ & $2.99-3.01$ & 4.88 & 4.5 & $4.20-4.55$ & 4.3 \\
$\mathbf{B}_{\mathbf{5}}$ & $1.55-1.63$ & $\mathrm{NR}$ & $\mathrm{NR}$ & $\mathrm{NR}$ & $\mathrm{NR}$ \\
$\mathbf{B}_{\mathbf{6}}$ & $0.40-0.43$ & 0.59 & 0.47 & $0.17-0.35$ & $\mathrm{NR}$ \\
$\mathbf{B}_{\mathbf{9}}$ & 0.02 & 0.02 & $\mathrm{NR}$ & 0.02 & $\mathrm{NR}$ \\
\hline
\end{tabular}

$\mathrm{B}_{1}$ - thiamin; $\mathrm{B}_{2}$ - riboflavin; $\mathrm{B}_{3}$ - niacin; $\mathrm{B}_{5}$ - pantothenic acid; $\mathrm{B}_{6}$ - pyridoxin; $\mathrm{B}_{9}$ - folic acid. Values are expressed in dry matter.

\subsection{Bioactive Constituents of Sorghum}

Sorghum grains and its subsequent food products are excellent sources of health promoting constituents including polyphenols, bioactive lipids, policosanols, phytosterols [62-65] and starch/carbohydrate fractions [66,67]. Numerous other properties of sorghum indicate its potential as a health food, including the absence of gluten (recommended for celiac and gluten celiac patients) and a relatively low glycemic index and load, thus reducing the risk of diabetes. The role of sorghum in lowering low-density lipoprotein (LDL), has also been reported, as well as its steroid-binding properties and its role in combating arthritis and rheumatism [65,68,69].

The most investigated bioactive component in sorghum are the polyphenols, which, in part, is due to the diversity of these compounds in sorghum grain. According to Awika [27] and Girard \& Awika [70], sorghum is the most diverse cereal in terms of the amounts and types of polyphenols present in them. It has one of the widest ranges of health beneficial components compared to other cereals [70]. The phenolic compounds include flavonoids, phenolic acids and condensed tannins (unique to few cereal grains) $[17,27,70]$. These condensed tannins (located in sorghum testa and pericarp) protect the seed against pest invasion, fungi, birds and other rodents [29]. Although tannins in sorghum can be considered desirable from an agronomic perspective, together with dhurrin (a cyanogenic glucoside in located mainly in the aerial shoot and sprouted seeds), they are considered the two major anti-nutritional factors (ANFs) in sorghum [29,71]. While tannin decreases starch and protein digestibility, cause dysfunction of cellular membranes and cause dysfunction of cellular membranes [29,70,72,73], dhurrin could cause cyanide poisoning (respiratory difficulty, nausea, abdominal distension [71,74]. Several processing methods, including fermentation, have, however, been reported to reduce these ANFs, improve digestibility and release bound nutrients and health beneficial components [11,29,70,75-79].

Dietary polyphenols in sorghum are reported to show high-antioxidant capacity when compared to other grains such as rice, millet, maize and wheat [80-83], which has been attributed to the redox chemistry of sorghum polyphenols [27]. Other beneficial effects of sorghum and its derived products include their ability to improve glycemic response, prevent cancer and confer anti-inflammatory effects. Other studies in the literature have also reported that sorghum phenolic extracts exert a protective effect to help prevent the onset of neurodegenerative related diseases, confer antidiabetic and anticancer effects, reduce swelling (oedema) and lower the incidence of oesophageal cancer [83-89]. Evidence for this has been demonstrated in previous studies and recently summarized in the reviews of Girard \& Awika [70] and Aruna \& Visarada [65]. This might also explain the interest and continued research into the role and effect of these compounds in sorghum and its exploration for mitigation of human health diseases. A viable route of ensuring that these benefits extend to humans would be through the incorporation of sorghum into diet. This could be through the appropriate transformation of sorghum grains into various other beneficial food forms, which would ensure possibility of obtaining various value-added food products. 


\section{Sorghum Fermentation}

While numerous techniques are available for the transformation of sorghum into other food forms, fermentation is still regarded as one of the oldest means of processing sorghum, and remains largely significant because of the beneficial functionalities it confers on foods. Fermentation can simply be defined as the intentional conversion/modification of a substrate into new products/forms, through microbial actions. This biochemical process is usually done with the goal of obtaining a specific product. As such, numerous changes occur during fermentation, leading to the modification of the sorghum substrate and production of metabolites. Such alterations influence taste, appearance, texture, color, flavor, shelf life and nutritional properties of derived products.

As with other fermentation processes, sorghum fermentation is generally classified into three categories viz.: spontaneous (also referred to as wild or natural), backslopping and controlled fermentation $[11,90]$. Spontaneous fermentation has been done for many years and basically involves the addition of water to sorghum and incubation of the mixture under suitable conditions of temperature and desired time. Fermentation during this process is usually through the sequential and competitive action of a plethora of microorganisms, with the best adapted strain(s), having a better growth rate, eventually dominating the microbiota. Microorganisms involved mainly come from the seed surface, and the subsequent changes are usually due to enzymatic activity exerted by these surface microorganisms, as well as endogenous enzymes in the grain. Occasional failure, slow fermentation rates, variation in qualities and lesser acidification probably led to a better craftmanship and the birth of backslopping $[90,91]$, which involves a re-innoculation of a previous successful fermentation batch into a new process, a procedure which guarantees a better fermentation process.

Advances in fermentation technologies and the increasing demand for fermented products of better and consistent quality have led to the use of starter cultures for a more controlled fermentation process [91,92]. This has necessitated the selection and identification of specific strains (starter cultures), with high competitiveness and shorter lag phases [93] and subsequent use of such organisms in controlled fermentation process. As such, various studies over the years have investigated the dominant strains in sorghum fermented foods and subsequently isolated, purified, characterized and preserved these microorganisms with the objective of using them to obtain final fermented products with the desired characteristics.

Generally, in sorghum, lactic acid bacteria (LAB) are the most dominant microorganisms during fermentation (Table 5), with lesser occurrence and reports of yeasts and fungi [91,93-95]. According to Teusink and Molenaar [96], environments in which LABs thrive are rich in proteins, sugars, vitamins, nucleotides and fats, and this could explain their predominance in sorghum microflora. It is also related to their high acidic tolerance and relative superiority in the utilization of starchy sorghum substrates, as well as the versatile carbohydrate metabolism thereof. According to Gänzle [97], this group of microorganisms are exploitative competitors, and inhibit other microorganisms through rapid utilization of abundant carbohydrates and accumulation of acetic and lactic acids. It is thus unsurprising that lactic acid fermentation is the most common form of sorghum fermentation type and mainly carried out by LABs (Table 5). LABs are generally recognized to be safe and beneficial, with some strains having health-promoting (probiotic) features. These group of microorganisms reduce the risk of fermentation failure and the fermentation period, while improving the value of the end product, as they have the ability to synthesize organic acids, inhibit food poisoning and spoilage bacteria through their antimicrobial, bactericidal and bacteriostatic effects [84,91,98]. The presence of other microorganisms is noteworthy, and they could have possibly participated in the fermentation process and/or are opportunistic microorganisms in the fermentation process. According to Capozzi [90], a broad diversity of microorganisms is associated with variety of raw materials used, fermentative behavior and nature of obtained products, and as such the multiplication and presence of these other undesired microorganisms might be difficult to control/limit in natural (spontaneous) fermentation. 
Table 5. Some African sorghum-based fermented food products and microorganisms associated with them.

\begin{tabular}{|c|c|c|c|c|}
\hline Product Name & Country/Region & Product Use & Microorganism Identified & Reference \\
\hline Aceda & Sudan & Porridge & Unknown & Eggum et al. [99]; Franz \& Holzapfel [100] \\
\hline Burukutu & West Africa & Alcoholic beverage & $\begin{array}{c}\text { Acetobacter spp., Candida spp., Enterobacter spp., } \\
\text { Lactobacillus spp., Saccharomyces cerevisiae, S. chavelieri, } \\
\text { Leuconostoc mesenteroides }\end{array}$ & $\begin{array}{l}\text { Kolawole et al. [101]; Eze et al. [102]; } \\
\text { Alo et al. [103]; Blandino et al. [104] }\end{array}$ \\
\hline Bushera & Uganda & Beverage & Lactobacillus brevis, L. delbrueckii, L. paracasei, L. plantarum & Marsh et al. [105]; Mwale [106] \\
\hline Chibuku & Zimbabwe & Alcoholic beverage & Lactobacillus spp. & Togo et al. [107]; Gadaga et al. [108] \\
\hline Dolo & Burkina Faso/Togo & Alcoholic beverage & $\begin{array}{l}\text { L. delbrueckii, L. fermentum, L. lactis, Pediococcus acidilactici, } \\
\text { S. cerevisae }\end{array}$ & $\begin{array}{l}\text { Van der Aa Kühle et al. [109]; } \\
\text { Sawadogo-Lingani et al. [110] }\end{array}$ \\
\hline Gowe & Benin & Porridge & L. fermentum, L. mucosae & Adinsi et al. [112]; Vieira-Dalodé et al. [113] \\
\hline Humulur & Sudan & Gruel & Bacillus spp., Lactobacillus spp., yeasts & Adams [114] \\
\hline Hussuwa & Sudan & Porridge & $\begin{array}{l}\text { A. xylinum, Gluconobacter oxydans, L. fermentum, } \\
\text { L. saccharolyticum, Pediococcus acidilactici, S. cerevisiae }\end{array}$ & Mwale [106]; Yousif et al. [115] \\
\hline Ikigage & Rwanda & Alcoholic beverage & $\begin{array}{l}\text { Issatchenkia orientalis, L. buchneri, L. fermentum, Lactobacillus } \\
\text { spp., S. cerevisiae }\end{array}$ & Lyumugabe et al. [116] \\
\hline Injera & Ethiopia & Sourdough/bread & C. guillermondii, Lactobacillus spp, yeasts & Dandessa et al. [117] \\
\hline Kisra & Sudan & Pancake, flat bread, sourdough & $\begin{array}{c}\text { C. intermedia, C. krusei, Debrayomyces hansenii, Enterococcus } \\
\text { faecium, L. amylovorus, L. brevis, L. confusus, L. fermentum, } \\
\text { Pichia kudriavzevii }\end{array}$ & $\begin{array}{l}\text { Mohammed et al. [118]; Hamad et al. [119]; } \\
\text { Ali \& Mustafa [120] }\end{array}$ \\
\hline Khamir & Sudan & Bread & L. brevis, L. cellobiosus & Gassem [121] \\
\hline Kunun-zaki & Nigeria & Beverage, breakfast meal & Ent. faecalis, Lactobacillus spp., P. pentosaceus, W. confusa & Franz \& Holzapfel [100] \\
\hline Mahewu & South Africa & Porridge gruel & $\begin{array}{l}\text { L. brevis, L. bulgaricus, L. delbruckii, Leuconostoc spp., } \\
\text { Streptococcus lactis }\end{array}$ & $\begin{array}{l}\text { Franz \& Holzapfel [100]; Hesseltine [122]; } \\
\text { Kayitesi et al. [123] }\end{array}$ \\
\hline Mbege & Tanzania & Beverage & $\begin{array}{l}\text { L. plantarum, Leuc. mesenteroides, S. cerevisiae, } \\
\text { Schizosaccharomyces pombe }\end{array}$ & Odunfa \& Oyewole [124] \\
\hline Merissa & Sudan & Alcoholic drink & Saccharomyces spp. & Dirar $[125,126]$ \\
\hline Nasha & Sudan & Infant food & Candida spp., Lactobacillus spp., S. cerevisiae, Strep. spp. & Graham et al. [127] \\
\hline Ogi & West Africa & Gruel & $\begin{array}{l}\text { L. acidophilus, L. agilis, L. cellobiosus, L. confusus, L. murinus, } \\
\text { L. plantarum }\end{array}$ & Graham et al. [127]; Omemu \& Bankole [128 \\
\hline Ori-ese & Nigeria & Porridge & $\begin{array}{l}\text { Bacillus subtilis, C. tropicalis, L. acidophilus, L. fermentum, } \\
\text { L. plantarum, Mucor spp., Pediococcus spp., Penicillium spp., } \\
\text { S. pombe }\end{array}$ & Adebayo-Tayo \& Needum [129] \\
\hline
\end{tabular}


Table 5. Cont.

\begin{tabular}{|c|c|c|c|c|}
\hline Product Name & Country/Region & Product Use & Microorganism Identified & Reference \\
\hline Orubisi & Tanzania & Alcoholic beverage & LABs, yeasts & Shayo et al. [130] \\
\hline Otika & Nigeria & Alcoholic beverage & $\begin{array}{c}\text { B. cereus, B. subtilis, C. krusei, C. tropicalis, } \\
\text { Enterobacter clocae, L. brevis, L. fermentum, L. plantarum, } \\
\text { Leuconostoc mesenteroides, S. cerevisae }\end{array}$ & Oriola et al. [131] \\
\hline Pito & Nigeria & Alcoholic beverage & $\begin{array}{l}\text { B. subtillis, Candida spp., Geotrichum candidum, } \\
\text { L. delbrueckii, L. fermentum }\end{array}$ & $\begin{array}{l}\text { Kolawole et al. [101], } \\
\text { Sawadogo-Lingani et al. [132]; } \\
\text { Ajiboye et al. [133] }\end{array}$ \\
\hline Tella & Ethiopia & Beverage & L. pastorianumi, S. cerevisae & Lemi [134] \\
\hline Tchoukoutou & Benin & Alcoholic beverage & $\begin{array}{l}\text { L. divergens, L. fermentum, L. fructivorans, S. cerevisae, } \\
\text { S. pastorianus, Torulasposa delbrueckii }\end{array}$ & Kayodé et al. [137,138] \\
\hline Ting & Botswana, South Africa & Porridge & $\begin{array}{l}\text { L. casei, L. coryniformis, L. curvatus, L. fermentum, } \\
\text { L. harbinensis, L. parabuchneri, L. plantarum, L. reuteri, } \\
\text { L. rhamnosus }\end{array}$ & $\begin{array}{c}\text { Madoroba et al. [139,140]; Sekwati-Monang } \\
\text { \& Gänzle [141] }\end{array}$ \\
\hline Thobwa & Malawi & Alcoholic beverage & Unknown & Nyanzi \& Jooste [98]; Matumba et al. [142] \\
\hline Uji & East Africa & Porridge & $\begin{array}{l}\text { L. cellobiosus, L. fermentum, L. plantarum, Ped. acidilactici, } \\
\text { Ped. pentosaceus }\end{array}$ & Blandino et al. [104] \\
\hline Weaning food & Nigeria & Weaning food & L. plantarum, Ped. acidilactici, S. cerevisae & Wakil \& Kazeem [144] \\
\hline
\end{tabular}


Sorghum fermentation usually results in changes to and the subsequent improvement of nutritional qualities, taste, shelf life, aroma and structural modification. Similar to other cereal fermentation processes, fermentation of sorghum leads to a modification (increase/decrease) of inherent metabolites and constituents (Figure 2), activation of enzymes, decrease in pH levels, increased metabolic activities and microbial actions with a consequent decrease in ANFs, detoxification and degradation of contaminants [9,11,17,145-153].
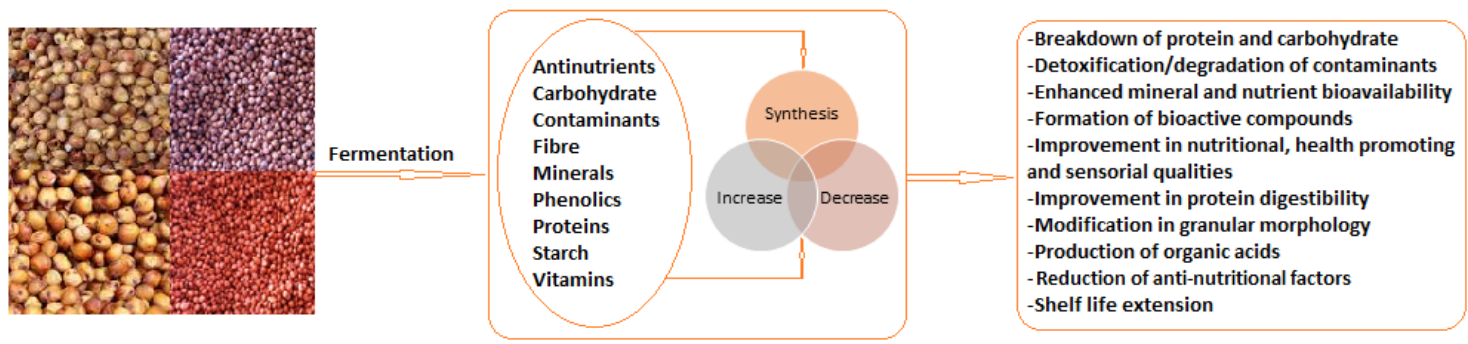

Figure 2. Modifications to sorghum during fermentation.

These modifications are, in part, due to proteolysis, with the possible formation of monomers from large molecules. Fermentation also leads to the production of enzymes that trigger the breakdown of substrates, improving the nutritional quality [154]. The production of organic acids, leading to a decrease in $\mathrm{pH}$ and a corresponding rise in titratable acidity, with accompanying changes in functional properties (such as emulsifying and oil- and water-binding capacity) have also been reported in the literature $[4,17,146,155]$.

In addition to these modifications, fermentation equally affects the amount and composition of phenolic compounds. The metabolism of phenolic compounds and an increase/decrease in antioxidant activities during fermentation have been extensively reported [11,17,91,156-160]. Through the metabolic activities of microbes, fermentation also induces the structural breakdown of the cell wall, leading to the synthesis of various bioactive compounds. Equally important are the roles of amylases, proteases and xylanases derived from the fermenting microorganisms, and the cereal grain that contributes to the modification of the grain and the distortion of the chemical bonds, consequently releasing bound phenolics [11]. During fermentation, these phenolic compounds are metabolized and modified by the fermenting organism into other conjugates, glucosides and/or related forms through decarboxylation and hydrolysis, as well as esterification $[11,159,160]$.

Not only do the metabolites produced inhibit the growth of pathogenic and spoilage microorganisms, they equally suppress them. Beyond its preservative effects, fermentation improves the palatability, nutritional profile and effects desirable organoleptic characteristics that impart the desired flavor, texture and aroma. Other benefits in addition to this are the extension of shelf life and the production of health beneficial constituents. The microbiology and biochemistry of the fermentation process have been well documented $[9,161,162]$, with these studies indicating that the endogenous microorganisms that are activated during the natural fermentation process or the starter cultures used facilitate the subsequent activities and production of several compounds that result in the aforementioned changes.

\section{African Sorghum Fermented Food Products: Traditional and Value Added Products}

Traditionally, the sorghum fermentation process is usually carried out in small and household scales. These are characterized by the use of indigenous, non-sterile equipment under unhygienic conditions, with unattractive packaging for the derived products. Furthermore, the inconsistencies of the ingredients and innoculum lead to $\mathrm{pH}$ variation in the final products. Due to the socio-economic, nutritional and cultural role these fermented foods play in African communities and households, concerted efforts have been made and studies have been conducted in improving the fermentation process for the development of indigenous fermented foods. This section provides an appraisal of 
traditional fermented sorghum-based products and their development into shelf-stable value-added products on the market.

Beverages are most probably one of the most consumed sorghum-based fermented products known. Both alcoholic and non-alcoholic African sorghum beverages are known under a variety of names (Table 4). While the traditional processing of these products has been documented in the literature, intensified efforts towards their developments have led to their availability on the market. From being traditionally brewed in local pots and served in calabash and traditional utensils, recent trends have seen them become products with significant socio-economic impacts. Their fermentation processes have been industrialized, and some of these products now flood the market in attractive packages and are readily available.

In tandem with recent trends of functional foods, researchers in South Africa created a functional beverage called niselo by including probiotics in a sorghum beverage to ensure consumers derive benefits beyond the inherent basic nutrition. Motoho, a non-alcoholic beverage from ting has also been recently developed through a modern commercial process by fermenting the sorghum with a specific commercial lactic acid bacteria strain, and the subsequent addition of chemical preservatives and additives [18]. A prominent Southern African sorghum-based opaque beer that is also readily available on the market is umqombothi. Through concerted efforts, these products have been industrialized, packaged, commercialized and made available in different flavors across Southern Africa.

Other fermented sorghum products of commercial importance and prominence are West African kunu and Ugandan bushera, which have evolved from products developed with traditional fermentation processes using calabash under unhygienic conditions into shelf stable products. According to Rosentrater and Evers [163], porridges made from cereals such as sorghum are one of the most important dishes consumed by the inhabitants of Sub-Saharan Africa. Both thick and thin porridges are made basically differing in the flour/water ratio required and consumed across ethnic divides. Successful products in this regard, which stemmed from their indigenous form to become commercially viable products, are $u j i$, a Kenyan gruel and ogi-baba, a sorghum-based fermented cereal pudding from Nigeria.

\section{Safety of African Sorghum Fermented Foods}

Irrespective of the region in the world, food safety issues remain critical for individuals, food businesses and the relevant authorities. Such safety concerns extend to that of fermented foods, despite the numerous advantages attributed to the consumption of these foods earlier highlighted herein. Reports of some studies have indicated the presence of opportunistic pathogens and/or their toxins in some African sorghum-based fermented foods (Table 6). An appropriate assessment of the risk associated with these reported pathogens should, however, be carefully considered, as cell counts and/or the frequency of their presence would indicate if they really are of concern in these foods.

Table 6. Some recorded cases of pathogens in African fermented sorghum-based foods.

\begin{tabular}{cccc}
\hline Food & Safety risk & Probable Source & Reference \\
\hline $\begin{array}{c}\text { Fermented sorghum } \\
\text { meal }\end{array}$ & Food pathogens & $\begin{array}{c}\text { B. cereus, Clostridium } \\
\text { perfringes, Escherichia coli, } \\
\text { Listeria monocytogenes }\end{array}$ & Kunene et al. [164] \\
\hline Hussuwa & $\begin{array}{c}\text { Hygienic risk, antimicrobial } \\
\text { resistances, biogenic amines, } \\
\text { presence of virulence } \\
\text { determinants }\end{array}$ & Yousif et al. [165] & \\
\hline Gowe & $\begin{array}{c}\text { Cyanogenic compounds, food } \\
\text { pathogens, mycotoxins }\end{array}$ & $\begin{array}{c}\text { E. coli, Enterobacteriacae, } \\
\text { mycotoxigenic fungi }\end{array}$ & Adinsi et al. [166] \\
\hline Ikigage & Food pathogens & E. coli, Streptococci & Lyumugabe et al. [116] \\
\hline
\end{tabular}


Table 6. Cont.

\begin{tabular}{cccc}
\hline Food & Safety risk & Probable Source & Reference \\
\hline Mahewu & Food pathogens & E. coli & $\begin{array}{c}\text { Simango and Rukure [167]; } \\
\text { Nyatoti et al. [168] }\end{array}$ \\
\hline Obushera & Food pathogens & E. coli, Staphylococcus & Byakika et al. [169] \\
\hline Ogi & Mycotoxins & Mycotoxigenic fungi & Adekoya et al. [170] \\
\hline Pito & Mycotoxins & Mycotoxigenic fungi & $\begin{array}{c}\text { Ezekiel et al. [148]; } \\
\text { Chilaka et al. [171] }\end{array}$ \\
\hline Thobwa & Mycotoxins & Mycotoxigenic fungi & Matumba et al. [142] \\
\hline Ting & Mycotoxins & Mycotoxigenic fungi & Adebo et al. [153] \\
\hline
\end{tabular}

Judging from numerous studies and reviews that have shown that fermentation and LABs are capable of reducing/degrading toxins and contaminants in foods $[147,150,151,153,172-176]$, it could be postulated that the levels found could either be 'residues' and or 'left-overs' of the fermentation process. The role of post contamination of these products should also not be ruled out as a possible source of these opportunistic microorganisms. Challenges of safety also arise with spontaneously fermented sorghum-based foods. This is in part due to the broad diversity of microorganisms causing an "unhealthy" competition among the fermenting microbiota, leading to the production of toxic by-products that compromise the safety of the food. Although much more prevalent in rural communities, safety issues of derived fermented foods can be traced to all or either of the following: (i) raw materials; (ii) processing equipment, items and materials; (iii) storage conditions and packaging; and/or (iv) biological, physical and chemical contaminants through processors/handlers and the processing environment. Since safety challenges in sorghum-based fermented foods (similar to other fermented foods) usually come from all or some of the aforementioned routes $[75,90,154]$, less contamination must be ensured in raw materials, whilst ensuring the sterility of processing equipment and all other items during the production of the fermented food. Equally important are hygienic conditions for the handling, packaging and storage of fermented foods, to mitigate against post-processing contamination.

Various scientific studies and evidences have demonstrated the crucial importance of starter cultures and other modern microbial biotechnological solutions in food fermentation to ensure food safety $[90,91]$. This desired effect has been attributed to various biological activities, including domination of the indigenous microflora, faster acidification, reduced fermentation time and the suppression of undesired microbial strains/species [177-179]. Over and above, while the contribution of fermentation to food safety is evident, it cannot eliminate all food related health risks and should thus not be considered a control measure.

\section{Future Projections}

Fermented foods, including sorghum-based fermented products, are of prominent significance to the economy, health and nutrition of Africa. The nutritional value and profile of sorghum needs to be improved using techniques like the development of novel sorghum lines in order to improve the digestibility of sorghum proteins and genetic modification for improved nutritional value $[180,181]$. While these propositions could be successful, it would be important for high sorghum eating populations to complement their diet with foods rich in an appropriate nutrient balance, such as vegetables, fruits, animal products and nutrient-dense plant sources such as legumes [182,183].

Innovations and improvements to ensure the sustainability of these products should thus be continuous. The wave of the fourth industrial revolution (4IR) cannot be overlooked, and its effective application in sorghum fermentation is still lacking. Strongly intertwined with 4IR are artificial intelligence (AI) and machine learning (ML), relatively new concepts, with current utilization and potential for solving numerous complex challenges. As with other fields, AI and ML have a huge role to play in fermentation, including but not limited to product development, ensuring safety, 
improvement in product efficiency and plant productivity. These techniques have been applied in other sorghum related studies: Kashiri et al. [184] utilized an artificial neural network (ANN) for simulating and predicting the soaking behavior of sorghum kernel as a function of temperature and time, while Kaliba et al. [185] estimated the propensity for and intensity of the adoption of improved sorghum varieties in Tanzania using deep learning techniques. Sebayang et al. [186] also adopted ANN to investigate the relationship between bioethanol production, enzymatic hydrolysis and fermentation. The authors were able to optimize bioethanol production from sorghum grains, and indicated the effectiveness of the approach in reducing cost, time and effort associated with experimental techniques [186]. Further detailed description, classification and use of these AI and ML techniques is available in the literature, and can be consulted for further reading [187-191]. The specific and potential immediate application of AI and ML to sorghum-based fermented foods include predictive product development and optimization of fermentation processes. As indicated by the Institute of Food Technologists (IFT) [192], with other fields having rapidly embraced these techniques, the food and beverage industry is still trying to catch up with its counterparts in other industries that are ahead of it, and thus it calls for increased efforts in this regard.

The advent of the "omics" technologies (metabolomics, genomics, metagenomics, transcriptomics, foodomics, volatilomics and proteomics) have also opened up possibilities of better understanding and broader perspectives into the quality of fermented foods $[8,64,91,193-196]$. These big data bioinformatic techniques have provided tools to control, monitor, modify or improve such products. They also assist in providing deeper insights into the underlying molecular mechanisms of fermented foods, the dynamics of the fermenting microbiota, metabolic interactions and functionalities, as well as nutraceutical potential of these group of foods. In the past, the microbiota of fermented foods has been characterized using culture dependent techniques, which only focuses on a group of microorganisms, with an assumption that these targeted microorganisms are responsible for the fermentation process. Metagenomics, a culture-independent technique involving the sequencing of all DNA extracted from a sample, changed the way food microbial ecology is studied [195-197]. By providing a broader understanding of the microbiota of fermented foods, this would effectively guide in the selection of starter cultures for an improved fermentation process. Likewise, metabolomics involves the analysis of metabolites within a sample interest to answer specific biological questions that would further provide insight or assist in the selection of strains, process, substrate $[8,195,197]$. Through these technologies, and the earlier aforementioned ones, new strains of starter cultures with desirable functionalities could be identified and purified for use in fermentation. Also, better understanding of the characteristics and functions of already established starter cultures of fermentative microorganisms could also be obtained.

Other areas that could be explored to improve sorghum utilization and contribute to food security include the use of whole sorghum grains for fermented foods, with the provision of desirable health benefits and beneficial compounds in subsequent products compared to products from refined grains $[11,160,198,199]$. Potential technologies that can equally be utilized include encapsulation to improve the delivery of desired compounds into food [200-202], the adoption of novel food technologies, such as high-pressure processing (HPP) [203,204], ohmic heating [205,206] and pulse electric field (PEF) [207], as well as other non-thermal food processing technologies [91,208,209].

\section{Conclusions}

Fermented foods comprise part of the identity of ethnic groups, are important in social traditions, cultural folklore and are also crucial from a health, nutritional and economic perspective. The current market for sorghum and subsequent fermented products is huge and still growing. Sorghum is a valuable grain, particularly due to its health beneficial constituents and its status as a practicable option for coeliac and gluten intolerant people (due to its absence of gluten). While sorghum is also good source of carbohydrates (starch) and energy, combining it (during the development of fermented foods) with other affordable nutrient-dense food sources would improve the nutritional quality of the resulting products and would assist in alleviating some of the malnutrition challenges in Africa. 
Challenges regarding the possible development of undesirable colors, odors and off-flavors might arise during the development of these products, but once addressed, the resultant food products could lead to the birth of new niche markets and also contribute to consumer health and wellness on the continent, as well as uplift an already ailing economy, when such products can thrive commercially. Diversity in the diet of African populations should nonetheless be emphasized, as a diverse diet would best ensure a wider range of health promoting compounds and much needed nutrient adequacy.

Funding: The University of Johannesburg Global Excellence and Stature (GES) 4.0 Catalytic Initiative Grant, UJ Research Committee (URC) Grant and the National Research Foundation (NRF) of South Africa Thuthuka funding (Grant no: 121826) are duly acknowledged.

Acknowledgments: The author wishes to appreciate the constructive comments of the reviewers for improving the quality of this manuscript.

Conflicts of Interest: The author declares no conflict of interest.

\section{References}

1. FAOSTAT Food and Agriculture Organization Statistics. Available online: http://www.fao.org/faostat/en/ \#data/QC (accessed on 31 March 2020).

2. Mabhaudhi, T.; O’Reilly, P.; Walker, S.; Mwale, S. Opportunities for underutilised crops in Southern Africa's post-2015 development agenda. Sustainability 2016, 8, 302. [CrossRef]

3. Sobowale, S.S.; Adebo, O.A.; Mulaba-Bafubiandi, A.F. Production of extrudate pasta from optimal-sorghum-peanut flour blend and influence of composite flours on some quality characteristics and sorption isotherms. Trans. Royal Soc. S. Afr. 2019, 74, 268-275. [CrossRef]

4. Adebo, O.A.; Njobeh, P.B.; Mulaba-Bafubiandi, A.F.; Adebiyi, J.A.; Desobgo, S.C.Z.; Kayitesi, E. Optimization of fermentation conditions for ting production using response surface methodology. J. Food Process Preserv. 2018, 42, e13381. [CrossRef]

5. Schober, T.J.; Bean, S.R. Sorghum and maize. In Gluten-Free Cereal Products and Beverages; Arendt, E.K., Bello, F.D., Eds.; Elsevier: Amsterdam, The Netherlands, 2008; pp. 101-118. [CrossRef]

6. Taylor, J.R.N.; Duodu, K.G. Sorghum and millets: Grain quality characteristics and management of quality requirements. In Cereal Grains; Wrigley, C., Batey, I., Miskelly, D., Eds.; Elsevier: Amsterdam, The Netherlands, 2017; pp. 317-351. [CrossRef]

7. Odunmbaku, L.A.; Sobowale, S.S.; Adenekan, M.K.; Oloyede, T.; Adebiyi, J.A.; Adebo, O.A. Influence of steeping duration, drying temperature, and duration on the chemical composition of sorghum starch. Food Sci. Nutr. 2018, 6, 348-355. [CrossRef]

8. Adebo, O.A.; Njobeh, P.B.; Adebiyi, J.A.; Gbashi, S.; Kayitesi, E. Food metabolomics (Foodomics), a new frontier in food analysis and its potential in understanding fermented foods. In Functional Food-Improve Health through Adequate Food; Hueda, M.C., Ed.; InTech: Rijeka, Croatia, 2017; pp. 211-234. [CrossRef]

9. Adebo, O.A.; Njobeh, P.B.; Adebiyi, J.A.; Gbashi, S.; Phoku, J.Z.; Kayitesi, E. Fermented pulse-based foods in developing nations as sources of functional foods. In Functional Food-Improve Health through Adequate Food; Hueda, M.C., Ed.; InTech: Rijeka, Croatia, 2017; pp. 77-109. [CrossRef]

10. Rosales, E.; Pasoz, M.; Sanroman, M.A. Solid-state fermentation for food applications. In Current Developments in Biotechnology and Bioengineering; Pandey, A., Larroche, C., Soccol, C., Eds.; Elsevier: Amsterdam, The Netherlands, 2018; pp. 319-355. [CrossRef]

11. Adebo, O.A.; Medina-Meza, I.E. Impact of fermentation on the phenolic compounds and antioxidant activity of whole cereal grains: A mini review. Molecules 2020, 25, 927. [CrossRef]

12. Xiang, H.; Sun-Waterhuse, D.; Waterhouse, G.I.N.; Cui, C.; Ruan, Z. Fermentation-enabled wellness foods: A fresh perspective. Food Sci. Hum. Well 2019, 8, 203-243. [CrossRef]

13. Galati, A.; Oguntoyinbo, F.A.; Moschetti, G.; Crescimanno, M.; Settanni, L. The cereal market and the role of fermentation in cereal-based food production in Africa. Food Rev. Int. 2014, 30, 317-337. [CrossRef]

14. Adebiyi, J.A.; Obadina, A.O.; Adebo, O.A.; Kayitesi, E. Fermented and malted millet products in Africa: Expedition from traditional/ethnic foods to industrial value added products. Crit. Rev. Food Sci. Nutr. 2018, 58, 463-474. [CrossRef] 
15. Tamang, J.P. Fermented foods for human life. In Microbes for Human Life; Chauhan, A.K., Verma, A., Kharakwal, H., Eds.; I.K International Publishing House Pvt: New Delhi, India, 2007; pp. 73-87. [CrossRef]

16. Farhad, M.; Kailasapathy, K.; Tamang, J.P. Health aspects of fermented food. In Fermented Foods and Beverages of the World; Tamang, J.P., Kailasapathy, K., Eds.; CRC Press: London, UK, 2010; pp. 391-414. [CrossRef]

17. Taylor, J.R.N.; Duodu, K.G. Effects of processing sorghum and millets on their phenolic phytochemicals and the implications of this to the health-enhancing properties of sorghum and millet food and beverage products. J. Sci. Food Agric. 2015, 95, 225-237. [CrossRef]

18. Alavi, S.; Mazumdar, S.D.; Taylor, J.R.N. Modern convenient sorghum and millet food, beverage and animal feed products, and their technologies. In Sorghum and Millets: Chemistry, Technology and Nutritional Attributes, 2nd ed.; Taylor, J.R.N., Duodu, K.G., Eds.; Elsevier: Amsterdam, The Netherlands, 2019; pp. $293-329$. [CrossRef]

19. Visarada, K.B.R.S.; Aruna, C. Sorghum: A Bundle of Opportunities in the 21st Century. In Breeding Sorghum for Diverse End Uses; Aruna, C., Visarada, K.B.R.S., Bhat, B.V., Tonapi, V.A., Eds.; Elsevier: Amsterdam, The Netherlands, 2019; pp. 1-14. [CrossRef]

20. Iqbal, M.A.; Iqbal, A. Overview on sorghum for food, feed, forage and fodder: Opportunities and problems in Pakistan's perspectives. Am.-Eurasian J. Agric. Environ. Sci. 2015, 15, 1818-1826. [CrossRef]

21. Wrigley, C. The cereal grains: Providing our food, feed and fuel needs. In Cereal Grains; Wrigley, C., Batey, I., Miskelly, D., Eds.; Elsevier: Amsterdam, The Netherlands, 2017; pp. 27-40. [CrossRef]

22. Rooney, L.W.; Serna-Sladiver, S.O. Sorghum. In Encyclopedia of Food Science and Nutrition; Caballero, B., Ed.; Elsevier: Amsterdam, The Netherlands, 2003; pp. 5370-5375. [CrossRef]

23. Grayboasch, R.A. The grain crops: An overview. In Encyclopedia of Food Grains, 2nd ed.; Wrigley, C., Corke, H., Seetharaman, K., Faubion, J., Eds.; Elsevier: Amsterdam, The Netherlands, 2016; pp. 16-21. [CrossRef]

24. Linder, H.P.; Lehmann, C.E.R.; Archibald, S.; Osborne, C.P.; Richardson, D.M. Global grass (Poaceae) success underpinned by traits facilitating colonization, persistence and habitat transformation. Biol. Rev. 2017, 93, 1125-1144. [CrossRef] [PubMed]

25. Ratnavathi, C.V.; Komala, V.V. Sorghum grain quality. In Sorghum Biochemistry: An Industrial Perspective; Ratnavathi, C.V., Patil, J.V., Chavan, U.D., Eds.; Elsevier: Amsterdam, The Netherlands, 2016; pp. 1-61. [CrossRef]

26. Eckhoff, S.R.; Watson, S.A. Corn and sorghum starch production. In Starch: Chemistry and Technology, 3rd ed.; BeMiller, J., Whistler, R., Eds.; Elsevier: Amsterdam, The Netherlands, 2009; pp. 373-439. [CrossRef]

27. Awika, J.M. Sorghum: Its unique nutritional and health-promoting attributes. In Gluten-Free Ancient Grains; Taylor, J.R.N., Awika, J.M., Eds.; Woodhead Publishing: Cambridge, UK, 2017; pp. 21-54. [CrossRef]

28. Pontieri, P.; Del Giudice, L. Sorghum: A novel and healthy food. Encycl. Food Health 2016, 33-43. [CrossRef]

29. Batey, I. The diversity of uses for cereal grains. In Cereal Grains; Wrigley, C., Batey, I., Miskelly, D., Eds.; Elsevier: Amsterdam, The Netherlands, 2017; pp. 41-53. [CrossRef]

30. Taylor, J.R.N.; Emmambux, M.N. Gluten-free cereal products and beverages. In Gluten-Free Foods and Beverages from Millets; Arendt, E.K., Bello, F.D., Eds.; Elsevier: Amsterdam, The Netherlands, 2018; pp. 119-148. [CrossRef]

31. Beta, T.; Corke, H.; Taylor, J.R.N. Starch properties of Barnard red, a South African red sorghum variety of significance in traditional African brewing. Starch 2000, 52, 467-470. [CrossRef]

32. Topping, D.L. Soluble fiber polysaccharides: Effects on plasma cholesterol and colonic fermentation. Nutr. Rev. 1991, 49, 195-203. [CrossRef] [PubMed]

33. Warrand, J. Healthy polysaccharides the next chapter in food products. Food Technol. Biotechnol. 2006, $44,355-370$.

34. Jones, R.W.; Beckwith, A.C. Proximate composition and proteins of three grain sorghum hybrids and their dry-mill fractions. J. Agric. Food Chem. 1970, 18, 33-36. [CrossRef]

35. Okoh, P.N.; Obilana, A.T.; Njoku, P.C.; Aduku, A.O. Proximate analysis, amino acid composition and tannin content of improved Nigerian sorghum varieties and their potential in poultry feeds. Anim. Feed Sci. Technol. 1982, 7, 359-364. [CrossRef]

36. Adebiyi, A.O.; Adebiyi, A.P.; Olaniyi, E.O. Nutritional composition of Sorghum bicolor starch hydrolyzed with amylase from Rhizopus sp. Afr. J. Biotechnol. 2005, 4, 1089-1094. [CrossRef] 
37. Shawrang, P.; Sadeghi, A.A.; Behgar, M.; Zareshahi, H.; Shahhoseini, G. Study of chemical compositions, anti-nutritional contents and digestibility of electron beam irradiated sorghum grains. Food Chem. 2011, 125, 376-379. [CrossRef]

38. Shargie, N. Physico-Chemical Characteristics and Nutritional Value of Sorghum Grain. Available online: http: //www.grainsa.co.za/physio-chemical-characteristics-and-nutritional-value-of-sorghum-grain (accessed on 31 March 2020).

39. Udachan, I.S.; Sahoo, A.K.; Hend, G.M. Extraction and characterization of sorghum (Sorghum bicolor L. Moench) starch. Int. Food Res. J. 2012, 19, 315-319.

40. Awadelkareem, A.M.; Hassan, E.G.; Fageer, A.S.M.; Sulieman, A.M.; Mustafa, A.M.I. The nutritive value of two sorghum cultivar. Int. J. Food Nutr. Sci. 2015, 4, 1-7.

41. Ndimba, R.; Grootboom, A.W.; Mehlo, L.; Mkhonza, N.L.; Kossmann, J.; Barnabas, A.D.; Mtshali, C.; Pineda-Vargas, C. Detecting changes in the nutritional value and elemental composition of transgenic sorghum grain. Nuclear Instr. Methods Phys. Res. B 2015, 363, 183-187. [CrossRef]

42. Singh, E.; Jain, P.K.; Sharma, S. Effect of different household processing on nutritional and anti-nutritional factors in Vigna aconitifolia and Sorghum bicolour (L.) Moench seeds and their product development. J. Med. Nutr. Nutraceut. 2015, 4, 95-100. [CrossRef]

43. Ape, D.I.; Nwogu, N.A.; Uwakwe, E.I.; Ikedinobi, C.S. Comparative proximate analysis of maize and sorghum bought from Ogbete main market of Enugu state, Nigeria. Greener J. Agric. Sci. 2016, 6, $272-275$. [CrossRef]

44. Jimoh, W.L.O.; Abdullahi, M.S. Proximate analysis of selected sorghum cultivars. Bayero. J. Pure Appl. Sci. 2017, 10, 285-288. [CrossRef]

45. Mohapatra, D.; Patel, A.S.; Kar, A.; Deshpande, S.S.; Tripathi, M.K. Effect of different processing conditions on proximate composition, antioxidants, anti-nutrients and amino acid profile of grain sorghum. Food Chem. 2019, 271, 129-135. [CrossRef]

46. Kamath, V.; Niketh, S.; Chandrashekar, A.; Rajini, P.S. Chymotryptic hydrolysates of $\alpha$-kafirin, the storage protein of sorghum (Sorghum bicolor) exhibited angiotensin converting enzyme inhibitory activity. Food Chem. 2007, 100, 306-311. [CrossRef]

47. Camargo-Filho, I.; Cortez, D.A.G.; Ueda-Nakamura, T.; Nakamura, C.V.; Dias-Filho, B.P. Antiviral activity and mode of action of a peptide isolated from Sorghum bicolor. Phytomedicine 2008, 15, 202-208. [CrossRef]

48. Lin, P.; Wong, J.H.; Ng, T.B.; Ho, V.S.; Xia, L. A sorghum xylanase inhibitor-like protein with highly potent antifungal, antitumor and HIV-1 reverse transcriptase inhibitory activities. Food Chem. 2013, 141, 2916-2922. [CrossRef]

49. Cruz, R.A.O.; López, J.L.C.; Aguilar, G.A.G.; García, H.A.; Gorinstein, S.; Romero, R.C.; Sánchez, M.R. Influence of sorghum karifin on serum lipid profile and antioxidant activity in hyperlipidemic rats (in vitro and in vivo studies). BioMed Res. Int. 2015, 164725. [CrossRef]

50. Khalil, J.K.; Sawaya, W.N.; Safi, W.F.; Al-Mohammad, H.M. Chemical composition and nutritional quality of sorghum flour and bread. Plant Food Hum. Nutr. 1984, 34, 141-150. [CrossRef]

51. Hulse, J.H.; Laing, E.M.; Pearson, O.E. Sorghum and Millets: Their Chemical Composition and Nutritive Value; Academic Press: New York, NY, USA, 1980.

52. Salunkhe, D.K.; Kadam, S.S.; Chavan, J.K. Nutritional quality of proteins in grain sorghum. Plant Food Hum. Nutr. 1977, 2, 187-205. [CrossRef]

53. Afify, A.E.M.R.; El-Beltagi, H.S.; Abd El-Salam, S.M.; Omran, A.A. Protein solubility, digestibility and fractionation after germination of sorghum varieties. PLoS ONE 2012, 7, e31154. [CrossRef] [PubMed]

54. Mabelele, M.; Siwela, M.; Gous, R.M.; Iji, A. Chemical composition and nutritive value of South African sorghum varieties as feed for broiler chickens. S. Afr. J. Anim. Sci. 2015, 45, 206-213. [CrossRef]

55. Shegro, A.; Shargie, N.G.; van Biljon, A.; Labuschagne, M.T. Diversity in starch, protein and mineral composition of sorghum landrace accessions from Ethiopia. J. Crop. Sci. Biotechnol. 2012, 15, 275-280. [CrossRef]

56. Pontieri, P.; Troisi, J.; Di Fiore, R.; Di Maro, A.; Bean, S.R.; Tuinstra, M.R.; Roemer, E.; Boffa, A.; Del Giddice, A.; Pizzolante, G.; et al. Mineral contents in grains of seven food-grade sorghum hybrids grown in a Mediterranean environment. Austr. J. Crop. Sci. 2014, 8, 1550-1559. 
57. Gerrano, A.S.; Labuschagne, M.T.; van Biljon, A.; Shargie, N.G. Quantification of mineral composition and total protein content in sorghum [Sorghum bicolor (L.) Moench] genotypes. Cereal Res. Comm. 2016, 44, 272-285. [CrossRef]

58. Serna-Saldivar, S.O.; Espinosa-Ramirez, J. Grain structure and grain chemical composition. In Sorghum and millets: Chemistry, Technology and Nutritional Attributes, 2nd ed.; Taylor, J.R.N., Duodu, K.G., Eds.; Elsevier: Amsterdam, The Netherlands, 2019; pp. 85-130. [CrossRef]

59. Kulamarva, A.G.; Sosle, V.R.; Raghavan, G.S.V. Nutritional and rheological properties of sorghum. Int. J. Food Prop. 2009, 12, 55-69. [CrossRef]

60. Ochanda, S.O.; Akoth, O.C.; Mwasaru, A.M.; Kagwiria, O.J.; Mutiso, M.F. Effects of malting and fermentation treatments on group B-vitamins of red sorghum, white sorghum and pearl millets in Kenya. J. Appl. Biosci. 2010, 34, 2128-2134.

61. Saleh, A.S.M.; Zhang, Q.; Chen, J.; Shen, Q. Millet grains: Nutritional quality, processing, and potential health benefits. Compr. Rev. Food Sci. Food Saf. 2013, 12, 281-295. [CrossRef]

62. Leguizamón, C.; Weller, C.L.; Schlegel, V.L.; Carr, T.P. Plant sterol and policosanol characterization of hexane extracts from grain sorghum, corn and their DDGS. J. Amer. Oil Chem. Soc. 2009, 86, 707-716. [CrossRef]

63. Lee, B.H.; Carr, T.P.; Weller, C.L.; Cuppett, S.; Dweikat, I.M.; Schlegel, V. Grain sorghum whole kernel oil lowers plasma and liver cholesterol in male hamsters with minimal wax involvement. J. Funct. Foods 2014, 7, 709-718. [CrossRef]

64. Adebo, O.A.; Kayitesi, E.; Tugizimana, F.; Njobeh, P.B. Differential metabolic signatures in naturally and lactic acid bacteria (LAB) fermented ting (a Southern African food) with different tannin content, as revealed by gas chromatography mass spectrometry (GC-MS)-based metabolomics. Food Res. Int. 2019, 121, 326-335. [CrossRef] [PubMed]

65. Aruna, C.; Visarada, K.B.R.S. Other industrial uses of sorghum. In Breeding Sorghum for Diverse End Uses; Aruna, C., Visarada, K.B.R.S., Bhat, B.V., Tonapi, V.A., Eds.; Elsevier: Amsterdam, The Netherlands, 2019; pp. 271-292. [CrossRef]

66. Khan, I.; Yousif, A.; Johnson, S.K.; Gamlath, S. Effect of sorghum flour addition on resistant starch content, phenolic profile and antioxidant capacity of durum wheat pasta. Food Res. Int. 2013, 54, 578-586. [CrossRef]

67. Licata, R.; Chu, J.; Wang, S.; Coorey, R.; James, A.; Zhao, Y.; Johnson, S. Determination of formulation and processing factors affecting slowly digestible starch, protein digestibility and antioxidant capacity of extruded sorghum-maize composite flour. Int. J. Food Sci. Technol. 2014, 49, 1408-1419. [CrossRef]

68. Kaur, K.D.; Jha, A.; Sabikhi, L.; Singh, A.K. Significance of coarse cereals in health and nutrition: A review. J. Food Sci. Technol. 2014, 51, 1429-1441. [CrossRef]

69. Rao, B.D.; Bharti, N.; Srinivas, K. Reinventing the commercialization of sorghum as health and convenient foods: Issues and challenges. Indian J. Econ. Dev. 2017, 13, 1-10. [CrossRef]

70. Girard, A.L.; Awika, J.M. Sorghum polyphenols and other bioactive components as functional and health promoting food ingredients. J. Cereal. Sci. 2018, 84, 112-124. [CrossRef]

71. Etuk, E.B.; Okuedo, N.J.; Esonu, B.O.; Udedibie, A.B.I. Antinutritional factors in sorghum: Chemistry, mode of action and effects on livestock and poultry. Online J. Anim. Feed Res. 2012, 2, 113-119.

72. Faquinello, P.; Murakami, A.E.; Cella, P.S.; Franco, J.R.G.; Sakamoto, M.I.; Bruno, L.D.G. High tannin sorghum in diets of Japanese quails (Coturnix coturnix japonica). Revista. Brasileira de Ciencia Avícola 2004, 6, 81-86. [CrossRef]

73. Goel, G.; Puniya, A.K.; Aguliar, C.N.; Singh, K. Interaction of gut microflora with tannins in feeds. Naturwissenschaften 2005, 92, 497-503. [CrossRef] [PubMed]

74. Aronson, J.K. Plant poisons and traditional medicines. In Manson's Tropical Infectious Diseases, 23rd ed.; Cereal grains Farrar, J., Hotez, P.J., Junghanss, T., Kang, G., Lalloo, D., White, N.J., Eds.; Elsevier: Amsterdam, The Netherlands, 2014; pp. 1128-1150. [CrossRef]

75. Proietti, I.; Frazzoli, C.; Mantovani, A. Exploiting nutritional value of staple foods in the world's semi-arid areas: Risks, benefits, challenges and opportunities of sorghum. Healthcare 2015, 3, 172-193. [CrossRef] [PubMed]

76. Obizoba, C.I.; Atii, J.V. Effect of soaking, sprouting, fermentation and cooking on nutrient composition and some anti-nutritional factors of sorghum (Guinesia) seeds. Plant Foods Hum. Nutr. 1991, 45, 23-34. [CrossRef] [PubMed] 
77. Mahgoub, S.E.O.; Elhag, S.A. Effect of milling, soaking, malting, heat-treatment and fermentation on phytate level of four Sudanese sorghum cultivars. Food Chem. 1998, 61, 77-80. [CrossRef]

78. Prasad, S.; Dhanya, M.S. Determination and detoxification of cyanide content in sorghum for ethanol production using Saccharomyces cerevisiae strain. J. Metab. Syst. Biol. 2011, 2, 10-14.

79. Ojha, P.; Adhikari, R.; Karki, R.; Mishra, A.; Subedi, U.; Karki, B.K. Malting and fermentation effects on antinutritional components and functional characteristics of sorghum flour. Food Sci. Nutr. 2018, 6, 47-53. [CrossRef]

80. Dykes, L.; Rooney, L.W. Phenolic compounds in cereal grains and their health benefits. Cereal. Foods World 2007, 52, 105-111. [CrossRef]

81. Dykes, L.; Rooney, L.W.; Waniska, R.D.; Rooney, W.L. Phenolic compounds and antioxidant activity of sorghum grains of varying genotypes. J. Agric. Food Chem. 2005, 53, 6813-6818. [CrossRef]

82. Dykes, L.; Rooney, L.W. Sorghum and millet phenols and antioxidants. J. Cereal. Sci. 2006, 44, $236-251$. [CrossRef]

83. Van Rensburg, S.J. Epidemiological and dietary evidence for a specific nutritional disposition to esophageal cancer. J. Natl. Cancer Inst. 1981, 67, 243-251.

84. Ly, D.; Mayrhofer, S.; Dimig, K.J. Significance of traditional fermented foods in the lower Mekong subregion: A focus on lactic acid bacteria. Food Biosci. 2018, 26, 113-125. [CrossRef]

85. Shih, C.H.; Siu, S.O.; Ng, R.; Wong, E.; Chiu, L.C.M.; Chu, I.K.; Lo, C. Quantitative analysis of anticancer 3-deoxyanthocyanidins in infected sorghum seedlings. J. Agric. Food Chem. 2007, 55, 254-259. [CrossRef] [PubMed]

86. Burdette, A.; Garner, P.L.; Mayer, E.P.; Hargrove, J.L.; Hartle, D.K.; Greenspan, P. Anti-inflammatory activity of select sorghum (Sorghum bicolor) brans. J. Med. Foods 2010, 13, 879-887. [CrossRef] [PubMed]

87. Oboh, G.; Akomolafe, T.L.; Adetuyi, A.O. Inhibition of cyclophosphamide-induced oxidative stress in brain by dietary inclusion of red dye extracts from sorghum (Sorghum bicolor) stem. J. Med. Foods 2010, 13, 1075-1080. [CrossRef] [PubMed]

88. Kim, J.; Park, Y. Anti-diabetic effect of sorghum extract on hepatic gluconeogenesis of streptozotocin-induced diabetic rats. Nutr. Metab. 2012, 9, 1-7. [CrossRef] [PubMed]

89. Taylor, J.R.N.; Belton, P.S.; Beta, T.; Duodu, K.G. Increasing the utilization of sorghum, millets and pseudocereals: Developments in the science of their phenolic phytochemicals, biofortification and protein functionality. J. Cereal. Sci. 2014, 59, 257-275. [CrossRef]

90. Capozzi, V.; Fragassa, M.; Romaniello, R.; Berbegal, C.; Russo, P.; Spano, G. Spontaneous food fermentations and potential risks for human health. Fermentation 2017, 3, 49. [CrossRef]

91. Adebo, O.A.; Njobeh, P.B.; Adeboye, A.S.; Adebiyi, J.A.; Sobowale, S.S.; Ogundele, O.M.; Kayitesi, E. Advances in fermentation technology for novel food products. In Innovations in Technologies for Fermented Food and Beverage Industries; Panda, S., Shetty, P., Eds.; Springer: Cham, Switzerland, 2018; pp. 71-87. [CrossRef]

92. Masebe, K.M.; Adebo, O.A. Production and quality characteristics of a probiotic beverage from watermelon (Citrullus lanatus). In Engineering, Technology and Waste Management (SETWM-19), Proceedings of the 17th Johannesburg International Conference on Science, Johannesburg, South Africa, 18-19 November 2019; Fosso-Kankeu, E., Waanders, F., Bulsara, H.K.P., Eds.; Eminent Association of Pioneers and North-West University: Johannesburg, South Africa, 2019; pp. 42-49. [CrossRef]

93. Brandt, M.J. Starter cultures for cereal based foods. Food Microbiol. 2014, 37, 41-43. [CrossRef]

94. Elkhalifa, A.E.O.; Ali, A.M.; El Tinay, A.H. Fermented sorghum foods of Sudan-a review. J. Food Sci. Technol. 2007, 44, 343-349.

95. Adebo, O.A.; Njobeh, P.B.; Adebiyi, J.A.; Kayitesi, E. Co-influence of fermentation time and temperature on physicochemical properties, bioactive components and microstructure of ting (a Southern African food) from whole grain sorghum. Food Biosci. 2018, 25, 118-127. [CrossRef]

96. Teusink, B.; Molenaar, D. Systems biology of lactic acid bacteria: For food and thought. Curr. Opin. Syst. Biol. 2017, 6, 7-13. [CrossRef]

97. Gänzle, M.G. Lactic metabolism revisited: Metabolism of lactic acid bacteria in food fermentations and food spoilage. Curr. Opin. Food Sci. 2015, 2, 106-117. [CrossRef]

98. Nyanzi, R.; Jooste, P.J. Cereal-based functional foods. In Probiotics; Rigobelo, E., Ed.; InTech: Rijeka, Croatia, 2012; pp. 161-196. [CrossRef] 
99. Eggum, B.O.; Monowar, L.; Back Knudsen, K.E.; Munck, L.; Axtell, J. Nutritional quality of sorghum and sorghum foods from Sudan. J. Cereal. Sci. 1983, 1, 127-137. [CrossRef]

100. Franz, C.M.A.P.; Holzapfel, W.H. Examples of lactic-fermented foods of the African continent. In Lactic Acid Bacteria: Microbiological and Functional Aspects; Vinderola, G., Ouwehand, A., Salminen, S., von Wright, A., Eds.; CRC Press: Boca Raton, FL, USA, 2019; pp. 235-254. [CrossRef]

101. Kolawole, O.M.; Kayode, R.M.O.; Akindayo, B. Proximate and microbial analyses of burukutu and pito produced in Ilorin. Nigeria. Afr. J. Biotechnol. 2007, 6, 587-590.

102. Eze, V.C.; Eleke, O.I.; Omeh, Y.S. Microbiological and nutritional qualities of burukutu sold in mammy market Abakpa, Enugu State, Nigeria. Am. J. Food Nutr. 2011, 1, 141-146. [CrossRef]

103. Alo, M.N.; Eze, U.A.; Eda, N.E. Microbiological qualities of burukutu produced from a mixture of sorghum and millet. Am. J. Food Nutr. 2012, 2, 96-102. [CrossRef]

104. Blandino, A.; Al-Aseeri, M.E.; Pandiella, S.S.; Cantero, D.; Webb, C. Cereal-based fermented foods and beverages. Food Res. Int. 2003, 36, 527-543. [CrossRef]

105. Marsh, A.J.; Hill, C.; Ross, R.P.; Cotter, P.D. Fermented beverages with health-promoting potential: Past and future perspectives. Trends Food Sci. Technol. 2014, 38, 113-124. [CrossRef]

106. Mwale, M.M. Microbiological quality and safety of the Zambian fermented cereal beverage: Chibwantu. Ph.D. Thesis, University of Free State, Bloemfontein, South Africa, 2014.

107. Togo, A.H.; Ferusa, B.S.; Mutukumira, N.A. Identification of lactic acid bacteria isolated from opaque beer (chibuku) for potential use as a starter culture. J. Food Technol. Afr. 2002, 7, 93-97. [CrossRef]

108. Gadaga, T.H.; Mutakumira, A.N.; Narvhus, J.A.; Ferusu, S.B. A review of traditional fermented foods and beverages in Zimbabwe. Int. J. Food Microbiol. 1999, 53, 1-11. [CrossRef]

109. Van der Aa Kühle, A.; Jespersen, L.; Glover, R.L.; Diawara, B.; Jakobsen, M. Identification and characterization of Saccharomyces cerevisiae strains isolated from West African sorghum beer. Yeast 2001, 18, 1069-1079. [CrossRef] [PubMed]

110. Sawadogo-Lingani, H.; Lei, V.; Diawara, B.; Nielsen, D.S.; Moller, P.L.; Traore, A.S.; Jakobsen, M. The biodiversity of predominant lactic acid bacteria in dolo and pito wort, for production of sorghum beer. J. Appl. Microbiol. 2007, 103, 765-777. [CrossRef] [PubMed]

111. Mukisa, I.M.; Ntaate, D.; Byakika, S. Application of starter cultures in the production of Enturire-A traditional sorghum-based alcoholic beverage. Food Sci. Nutr. 2017, 5, 609-616. [CrossRef] [PubMed]

112. Adinsi, L.; Vieira-Dalode, G.; Akissoe, N.H.; Anihouvi, V.; Mestres, C.; Jacobs, A.; Dlamini, N.; Pallet, D.; Hounhouigan, J.D. Processing and quality attributes of gowe: A malted and fermented cereal-based beverage from Benin. Food Chain 2014, 4, 171-183. [CrossRef]

113. Vieira-Dalodé, G.; Jespersen, L.; Hounhouigan, J.; Moller, P.L.; Nago, C.M.; Jakobsen, M. Lactic acid bacteria and yeasts associated with gowé production from sorghum in Bénin. J. Appl. Microbiol. 2007, 103, 342-349. [CrossRef] [PubMed]

114. Adams, M.R. Fermented weaning foods. In Microbiology of Fermented Foods; Wood, B.J.B., Ed.; Thomson Science: London, UK, 1998; pp. 790-811. [CrossRef]

115. Yousif, N.M.K.; Huch, M.; Schuster, T.; Cho, G.S.; Dirar, H.A.; Holzapfel, W.H.; Franz, C.M.A.P. Diversity of lactic acid bacteria from Hussuwa, a traditional African fermented sorghum food. Food Microbiol. 2010, 6, 757-768. [CrossRef] [PubMed]

116. Lyumugabe, F.; Kamaliza, G.; Bajyana, E.; Thonart, P. Microbiological and physico-chemical characteristic of Rwandese traditional beer "Ikigage". Afr. J. Biotechnol. 2010, 9, 4241-4246.

117. Dandessa, C. Review on Ethiopian traditional fermented foods, its microbial ecology and nutritional value. Int. J. Curr. Res. Acad. Rev. 2019, 7, 13-27. [CrossRef]

118. Mohammed, S.I.; Steenson, L.R.; Kirleis, A.W. Isolation and characterization of microorganisms associated with the traditional sorghum fermentation for production of Sudanese Kisra. Appl. Environ. Microbiol. 1991, 57, 2529-2533. [CrossRef]

119. Hamad, S.H.; Dieng, M.C.; Ehrmann, M.A.; Vogel, R.F. Characterization of the bacterial flora of Sudanese sorghum, flour and sorghum sourdough. J. Appl. Microbiol. 1997, 28, 764-770. [CrossRef]

120. Ali, A.A.; Mustafa, M.M. Isolation, characterization and identification of lactic acid bacteria from fermented sorghum dough used in Sudanese kisra preparation. Pakistan J. Nutri. 2009, 8, 1814-1818. [CrossRef]

121. Gassem, M.A.A. Study of micro-organisms associated with the fermented bread (khamir) produced from sorghum in Gizan region, Saudi Arabia. J. Appl. Microbiol. 1999, 86, 221-225. [CrossRef] [PubMed] 
122. Hesseltine, C.W. Some important fermented foods in mid-Asia, the Middle East and Africa. J. Amer. Oil Chem. Soc. 1979, 56, 367-374. [CrossRef] [PubMed]

123. Kayitesi, E.; Behera, S.K.; Panda, S.K.; Dlamini, B.C.; Mulaba-Bafubiandi, A.F. Amasi and mageu: Expedition from ethnic Southern African foods to cosmopolitan markets. In Fermented Food-Part II: Technological Interventions; Ray, R.C., Montet, D., Eds.; CRC Press: Boca Raton, FL, USA, 2017; pp. 384-399.

124. Odunfa, S.A.; Oyewole, O.B. African Fermented Foods; Blackie Academic and Professional: London, UK, 1997. [CrossRef]

125. Dirar, H.A. The Indigenous Fermented Foods of the Sudan; C.A.B. International: Wallingford, UK, 1993.

126. Dirar, H.A. The fermented foods of the Sudan. Ecol. Food Nutr. 1994, 32, 207-218. [CrossRef]

127. Graham, G.G.; MacLean, W.C.; Morales, E.; Hamaker, B.R.; Kirleis, A.W.; Mertz, E.T.; Axtell, J.D. Digestibility and utilization of protein and energy from Nasha, a traditional Sudanese fermented sorghum weaning food. J. Nutr. 1986, 116, 978-984. [CrossRef] [PubMed]

128. Omemu, A.M.; Bankole, M.O. Consumer's knowledge, attitude, usage and storage pattern of ogi-a fermented cereal gruel in South West, Nigeria. Food Public Health 2015, 5, 77-83. [CrossRef]

129. Adebayo-Tayo, B.C.; Needum, G.E. Microbiological, physicochemical and sensory evaluation of "ori-ese" produced from fortified sorghum. Afr. J. Food Agric. Nutr. Dev. 2011, 11, 4785-4799. [CrossRef]

130. Shayo, N.B.; Kamala, A.; Gidamis, A.B.; Nnko, S.A. Aspects of manufacture, composition and safety of orubisi: A traditional alcoholic beverage in the north-western region of Tanzania. Int. J. Food Sci. Nutr. 2000, 51, 395-402. [CrossRef] [PubMed]

131. Oriola, O.B.; Boboye, B.E.; Adetuyi, F.C. Bacterial and fungal communities associated with the production of a Nigerian fermented beverage, "otika". Jordan J. Biolog. Sci. 2017, 10, 127-133.

132. Sawadogo-Lingani, H.; Diawara, B.; Traore, A.S.; Jakobsen, M. Technological properties of Lactobacillus fermentum in the processing of dolo and pito, West African sorghum beers, for selection of starter cultures. J. Appl. Microbiol. 2008, 104, 873-882. [CrossRef] [PubMed]

133. Ajiboye, T.O.; Iliasu, G.A.; Adeleye, A.O.; Abdussalam, F.A.; Akinpelu, S.A.; Ogunbode, S.M.; Jimoh, S.O.; Oloyede, O.B. Nutritional and antioxidant dispositions of sorghum/millet beverages indigenous to Nigeria. Food Sci. Nutr. 2014, 2, 597-604. [CrossRef] [PubMed]

134. Lemi, B.W. Microbiology of Ethiopian traditionally fermented beverages and condiments. Int. J. Microbiol. 2020, 1478536. [CrossRef]

135. Djè, K.M.; Aka, S.; Zinzendorf, N.Y.; Yao, K.C.; Loukou, Y.G. Predominant lactic acid bacteria involved in the spontaneous fermentation step of tchapalo process, a traditional sorghum beer of Côte d'Ivoire. Res. J. Biol. Sci. 2009, 4, 789-795.

136. N'guessan, K.F.; Brou, K.; Jacques, N.; Casaregola, S.; Djè, K.M. Identification of yeasts during alcoholic fermentation of tchapalo, a traditional sorghum beer from Côte d'Ivoire. Antonie Van Leeuwenhoek 2011, 99, 855-864. [CrossRef] [PubMed]

137. Kayodé, A.P.P.; Adegbidi, A.; Hounhouigan, J.D.; Linnemann, A.R.; Nout, M.J.R. Quality of farmer's varieties of sorghum and derived foods as perceived by consumers in Benin. Ecol. Food Nutr. 2005, 44, 271-294. [CrossRef]

138. Kayodé, A.P.P.; Hounhouigana, J.D.; Nout, M.J.R. Impact of brewing process operations on phyta, phenolic compounds and in vitro solubility of iron and zinc in opaque sorghum beer. LWT 2007, 40, 834-841. [CrossRef]

139. Madoroba, E.; Steenkamp, E.T.; Theron, J.; Huys, G.; Scheirlinck, I.; Cloete, T.E. Polyphasic taxonomic characterization of lactic acid bacteria isolated from spontaneous sorghum fermentations used to produce ting, a traditional South African food. Afr. J. Biotechnol. 2009, 8, 458-463.

140. Madoroba, E.; Steenkamp, E.T.; Theron, J.; Scheirlinck, I.; Cloete, T.E.; Huys, G. Diversity and dynamics of bacterial populations during spontaneous sorghum fermentations used to produce ting, a South African food. Syst. Appl. Microbiol. 2011, 34, 227-234. [CrossRef]

141. Sekwati-Monang, B.; Gänzle, M.G. Microbiological and chemical characterization of ting, a sorghum-based sourdough product from Botswana. Int. J. Food Microbiol. 2011, 150, 115-121. [CrossRef]

142. Matumba, L.; Monjerezi, M.; Khonga, E.B.; Lakudzala, D.D. Aflatoxins in sorghum, sorghum malt and traditional opaque beer in southern Malawi. Food Cont. 2011, 22, 266-268. [CrossRef]

143. Katongole, J.N. The microbial succession in indigenous fermented maize products. Master's Thesis, University of the Free State, Bloemfontein, South Africa, 2008. 
144. Wakil, S.M.; Kazeem, M.O. Quality assessment of weaning food produced from fermented cereal-legume blends using starters. Int. Food Res. J. 2012, 19, 1679-1685.

145. Osman, M.A. Changes in sorghum enzyme inhibitors, phytic acid, tannins and in vitro protein digestibility occurring during khamir (local bread) fermentation. Food Chem. 2004, 88, 129-134. [CrossRef]

146. Kohajdova, Z.; Karovicova, J. Fermentation of cereals for specific purpose. J. Food Nutr. Res. 2007, 46, 51-57.

147. Kaushik, G.; Satya, S.; Naik, S.N. Food processing a tool to pesticide residue dissipation-A review. Food Rev. Int. 2009, 42, 26-40. [CrossRef]

148. Ezekiel, C.N.; Abia, W.A.; Ogara, I.M.; Sulyok, M.; Warth, B.; Krska, R. Fate of mycotoxins in two popular traditional cereal-based beverages (kunu-zaki and pito) from rural Nigeria. LWT-Food Sci. Technol. 2015, 60, 137-141. [CrossRef]

149. Karlovsky, P.; Suman, M.; Berthiller, F.; De Meester, J.; Eisenbrand, G.; Perrin, I.; Oswald, I.P.; Speijers, G.; Chiodini, A.; Recker, T.; et al. Impact of food processing and detoxification treatments on mycotoxin contamination. Mycotoxin Res. 2016, 32, 179-205. [CrossRef]

150. Adebiyi, J.A.; Kayitesi, E.; Adebo, O.A.; Changwa, R.; Njobeh, P.B. Food fermentation and mycotoxin detoxification: An African perspective. Food Cont. 2019, 106, 106731. [CrossRef]

151. Adebo, O.A.; Njobeh, P.B.; Gbashi, S.; Nwinyi, O.C.; Mavumengwana, V. Review on microbial degradation of aflatoxins. Crit. Rev. Food Sci. Nutr. 2017, 57, 3208-3217. [CrossRef]

152. Adebo, O.A. Metabolomics, Physicochemical properties and mycotoxin reduction of whole grain ting (a Southern African fermented food) produced via natural and lactic acid bacteria (LAB) fermentation. Ph.D. Thesis, University of Johannesburg, Johannesburg, South Africa, October 2018.

153. Adebo, O.A.; Kayitesi, E.; Njobeh, P.B. Reduction of mycotoxins during the fermentation of whole grain sorghum to whole grain ting (a Southern African food). Toxins 2019, 11, 180. [CrossRef]

154. Prakash, J. Safety of fermented cereals and legumes. In Regulating Safety of Traditional and Ethnic Foods; Prakash, V., Martin-Belloso, O., Keener, L., Astley, S., Braun, S., McMahon, H., Lelieveld, H., Eds.; Elsevier: Amsterdam, The Netherlands, 2016; pp. 283-310. [CrossRef]

155. Correia, I.; Nunes, A.; Guedes, S.; Barros, A.S.; Delgadillo, I. Screening of lactic acid bacteria potentially useful for sorghum fermentation. J. Cereal. Sci. 2010, 52, 9-15. [CrossRef]

156. Towo, E.; Matuschek, E.; Svanberg, U. Fermentation and enzyme treatment of tannin sorghum gruels: Effects on phenolic compounds, phytate and in vitro accessible iron. Food Chem. 2006, 94, 369-376. [CrossRef]

157. Dlamini, N.R.; Taylor, J.R.N.; Rooney, L.W. The effect of sorghum type and processing on the antioxidant properties of African sorghum-based foods. Food Chem. 2007, 105, 1412-1419. [CrossRef]

158. Curiel, J.A.; Rodríguez, H.; Acebrón, I.; Mancheño, J.M.; de las Rivas, B.; Muñoz, R. Production and physicochemical properties of recombinant Lactobacillus plantarum tannase. J. Agric. Food Chem. 2009, 57, 6224-6230. [CrossRef] [PubMed]

159. Svensson, L.; Sekwati-Monang, B.; Lutz, D.L.; Schieber, A.; Gänzle, M.G. Phenolic acids and flavonoids in nonfermented and fermented red sorghum (Sorghum bicolor (L.) Moench). J. Agric. Food Chem. 2010, 58, 9214-9220. [CrossRef]

160. Adebo, O.A.; Njobeh, P.B.; Kayitesi, E. Fermentation by Lactobacillus fermentum strains (singly and in combination) enhances the properties of ting from two whole grain sorghum types. J. Cereal. Sci. 2018, 82, 49-56. [CrossRef]

161. Odunfa, S.A.; Oyewole, O.B. African fermented foods. In Microbiology of Fermented Foods; Wood, B.J.B., Ed.; Springer: Boston, MA, USA, 1998; pp. 713-752. [CrossRef]

162. Anagnostopoulos, D.A.; Tsaltas, D. Fermented foods and beverages. In Innovations in Traditional Foods; Galanakis, C., Ed.; Woodhead Publishing: Cambridge, UK, 2019; pp. 257-291. [CrossRef]

163. Rosentrater, K.A.; Evers, A.D. Other food products. In Kent's Technology of Cereals, 5th ed.; Elsevier: Amsterdam, The Netherlands, 2018; pp. 699-727. [CrossRef]

164. Kunene, N.F.; Hastings, J.W.; von Holy, A. Bacterial populations associated with a sorghum-based fermented weaning cereal. Int. J. Food Microbiol. 1999, 49, 75-83. [CrossRef]

165. Yousif, N.M.K.; Dawyndt, P.; Abriouel, H.; Wijaya, A.; Schillinger, U.; Vancanneyt, M.; Swings, J.; Dirar, H.A.; Holzapfel, W.H.; Franz, C.M.A.P. Molecular characterization, technological properties and safety aspects of enterococci from 'Hussuwa', an African fermented sorghum product. J. Appl. Microbiol. 2005, 98, 216-228. [CrossRef] [PubMed] 
166. Adinsi, L.; Mestres, C.; Akisoé, N.; Vieira-Dalodé, G.; Anihouvi, V.; Durand, N.; Hounhouigan, D.J. Comprehensive quality and potential hazards of gowe, a malted and fermented cereal beverage from West Africa. A diagnostic for a future re-engineering. Food Cont. 2017, 82, 18-25. [CrossRef]

167. Simango, C.; Rukure, G. Survival of Campylobacter jejuni and pathogenic Escherichia coli in mahewu, a fermented cereal gruel. Trans. R. Soc. Trop. Med. Hyg. 1991, 85, 399-400. [CrossRef]

168. Nyatoti, V.N.; Mtero, S.; Rukure, G. Pathogenic Escherichia coli in traditional African weaning foods. Food Cont. 1997, 8, 51-54. [CrossRef]

169. Byakika, S.; Mukisa, I.V.; Byaruhanga, Y.B.; Male, D.; Muyanja, C. Influence of food safety knowledge, attitudes and practices of processors on microbiological quality of commercially produced traditional fermented cereal beverages, a case of Obushera in Kampala. Food Cont. 2019, 100, 212-219. [CrossRef]

170. Adekoya, I.; Njobeh, P.; Obadina, O.; Chilaka, C.; Okoth, S.; De Boevre, M.; De Saeger, S. Awareness and prevalence of mycotoxin contamination in selected Nigerian fermented foods. Toxins 2017, 9, 363. [CrossRef] [PubMed]

171. Chilaka, C.A.; De Boevre, M.; Atanda, O.O.; De Saeger, S. Quantification of Fusarium mycotoxins in Nigerian traditional beers and spices using a multi-mycotoxin LC-MS/MS method. Food Cont. 2018, 87, 203-210. [CrossRef]

172. Turbic, A.; Ahokas, J.T.; Haskard, C.A. Selective in vitro binding of dietary mutagens, individually or in combination, by lactic acid bacteria. Food Addit. Contam. 2002, 19, 144-152. [CrossRef]

173. Zhou, X.W.; Liu, H.F.; Zhao, X.H. The potencies of three microorganisms to dissipate four organophosphorus pesticides in three food materials during traditional fermentation. J. Food Sci. Technol. 2015, 52, 7353-7360. [CrossRef]

174. Trinder, M.; McDowell, T.W.; Daisley, B.A.; Ali, S.N.; Leong, H.S.; Sumarah, M.W.; Reid, G. Probiotic Lactobacillus rhamnosus reduces organophosphate pesticide absorption and toxicity to Drosophila melanogaster. Appl. Environ. Microbiol. 2016, 82, 6204-6213. [CrossRef]

175. Pinto, G.D.A.; Castro, I.M.; Miguel, M.A.L.; Koblitz, M.G.B. Lactic acid bacteria - Promising technology for organophosphate degradation in food: A pilot study. LWT-Food Sci. Technol. 2019, 353-359. [CrossRef]

176. Zhai, Q.; Guo, Y.; Tang, X.; Tian, F.; Zhao, J.; Zhang, H. Removal of cadmium from rice by Lactobacillus plantarum fermentation. Food Cont. 2019, 96, 357-364. [CrossRef]

177. Shukla, S.; Park, H.-K.; Lee, J.-S.; Kim, J.-K.; Kim, M. Reduction of biogenic amines and aflatoxins in doenjang samples fermented with various meju as starter cultures. Food Cont. 2014, 42, 181-187. [CrossRef]

178. De Angelis, M.; Campanella, D.; Cosmai, L.; Summo, C.; Rizzello, C.G.; Caponio, F. Microbiota and metabolome of un-started and started Greek-type fermentation of Bella di Cerignola table olives. Food Microbiol. 2015, 52, 18-30. [CrossRef]

179. Sanchart, C.; Rattanaporn, O.; Haltrich, D.; Phukpattaranont, P.; Maneerat, S. Enhancement of gamma-aminobutyric acid (GABA) levels using an autochthonous Lactobacillus futsaii CS3 as starter culture in Thai fermented shrimp (Kung-Som). World J. Microbiol. Biotechnol. 2017, 33, 152. [CrossRef] [PubMed]

180. Oria, M.P.; Hamaker, B.R.; Axtell, J.D.; Huang, C.-P. A highly digestible sorghum mutant cultivar exhibits unique folded structure of endosperm protein bodies. Proc. Natl. Acad. Sci. USA 2000, 97, 5065-5070. [CrossRef] [PubMed]

181. Elkonin, L.; Italyanskaya, J.; Panin, V. Genetic modification of sorghum for improved nutritional value: State of the problem and current approaches. J. Investig. Genom. 2018, 5, 39-48. [CrossRef]

182. Latham, M.C. Human Nutrition in the Developing World; FAO Food and Nutrition Series; FAO: Rome, Italy, 1997.

183. Temba, M.C.; Njobeh, P.B.; Adebo, O.A.; Olugbile, A.O.; Kayitesi, E. The role of compositing cereals with legumes to alleviate protein energy malnutrition in Africa. Int. J. Food Sci. Technol. 2016, 51, 543-554. [CrossRef]

184. Kashiri, M.; Garmakhany, A.D.; Dehghani, A.A. Modelling of sorghum soaking using artificial neural networks (MLP). Qual. Assur. Saf. Crops. 2012, 4, 179-184. [CrossRef]

185. Kaliba, A.R.; Mushi, R.J.; Gongwe, A.G.; Mazvimavi, K. A typology of adopters and nonadopters of improved sorghum seeds in Tanzania: A deep learning neural network approach. World Dev. 2020, 127, 104839. [CrossRef] 
186. Sebayang, A.H.; Masjuki, H.H.; Ong, H.C.; Dharma, S.; Silitonga, A.S.; Kusumo, F.; Milano, J. Optimization of bioethanol production from sorghum grains using artificial neural networks integrated with ant colony. Ind. Crop. Prod. 2017, 97, 146-155. [CrossRef]

187. Zhou, L.; Zhang, C.; Liu, F.; Qiu, Z.; He, Y. Application of deep learning in food: A review. Compr. Rev. Food Sci. Food Saf. 2019, 18, 1793-1811. [CrossRef]

188. Yordi, E.G.; Koelig, R.; Matos, M.J.; Martinez, A.P.; Caballero, Y.; Santana, L.; Quintana, M.P.; Molina, E.; Uriarte, E. Artificial intelligence applied to flavonoid data in food matrices. Foods 2019, 8, 573. [CrossRef]

189. Huang, Y.; Kangas, L.J.; Rasco, B.A. Applications of artificial neural networks (ANNs) in food science. Crit. Rev. Food Sci. Nutr. 2007, 47, 113-126. [CrossRef]

190. Goel, L.; Raman, S.; Dora, S.S.; Bhutani, A.; Aditya, A.S.; Mehta, A. Hybrid computational intelligence algorithms and their applications to detect food quality. Artif. Intell. Rev. 2020, 53, 1415-1440. [CrossRef]

191. Marwala, T.; Hurwitz, E. Introduction to man and machines. In Artificial Intelligence and Economic Theory: Skynet in the Market; Marwala, T., Hurwitz, E., Eds.; Springer: Cham, Switzerland, 2017; pp. 1-13. [CrossRef]

192. IFT (Institute of Food Technologists). Getting smart about artificial intelligence. Food Technol. Mag. 2018, $72,27$.

193. Zagorec, M.; Chaillou, S.; Champomier-Vergès, M.C.; Coq, A.M.C.L. Role of bacterial 'omics' in food fermentation. In Molecular Techniques in the Microbial Ecology of Fermented Foods; Cocolin, L., Ercolini, D., Eds.; Springer: New York, NY, USA, 2008; pp. 255-273. [CrossRef]

194. Alkema, W.; Boekhorst, J.; Wels, M.; van Hijum, S.A.F.T. Microbial bioinformatics for food safety and production. Brief Bioinform. 2016, 17, 283-292. [CrossRef] [PubMed]

195. Chen, G.; Chen, C.; Lei, Z. Meta-omics insights in the microbial community profiling and functional characterization of fermented foods. Trends Food Sci. Technol. 2017, 65, 23-31. [CrossRef]

196. Weckx, S.; Van Kerrebroeck, S.; De Vuyst, L. Omics approaches to understand sourdough fermentation processes. Int. J. Food Microbiol. 2018, 302, 90-102. [CrossRef] [PubMed]

197. De Filippis, F.; Parente, E.; Ercolini, D. Metagenomics insights into food fermentations. Microb Biotechnol. 2017, 10, 91-102. [CrossRef]

198. McRae, M.P. Health benefits of dietary whole grains: An umbrella review of meta-analyses. J. Chiropr. Med. 2017, 16, 10-18. [CrossRef]

199. Schaffer-Lequart, C.; Lehmann, U.; Ross, A.B.; Roger, O.; Eldridge, A.L.; Ananta, E.; Bietry, M.F.; King, L.R.; Moroni, A.V.; Srichuwong, S.; et al. Whole grain in manufactured foods: Current use, challenges and the way forward. Crit. Rev. Food Sci. Nutr. 2017, 57, 1562-1568. [CrossRef] [PubMed]

200. Links, M.R.; Taylor, J.; Kruger, M.C.; Taylor, J.R. Sorghum condensed tannins encapsulated in kafirin microparticles as a nutraceutical for inhibition of amylases during digestion to attenuate hyperglycaemia. J. Funct. Foods 2015, 12, 55-63. [CrossRef]

201. García-Gurrola, A.; Rincón, S.; Escobar-Puentes, A.A.; Zepeda, A.; Martínez-Bustos, F. Microencapsulation of red sorghum phenolic compounds with esterified sorghum starch as encapsulant materials by spray drying. Food Technol. Biotechnol. 2019, 57, 341-349. [CrossRef]

202. Khan, M.A.; Fang, Z.; Wusigale; Cheng, H.; Gao, Y.; Deng, Z.; Liang, L. Encapsulation and protection of resveratrol in kafirin and milk protein nanoparticles. Int. J. Food Sci. Technol. 2019, 54, 2998-3007. [CrossRef]

203. Vallons, K.J.R.; Ryan, L.A.M.; Koehler, P.; Arendt, E.K. High pressure-treated sorghum flour as a functional ingredient in the production of sorghum bread. Euro. Food Res. Technol. 2010, 231, 711-717. [CrossRef]

204. Correia, I.; Nunes, A.; Saraiva, J.A.; Barros, A.S.; Delgadillo, I. High pressure treatments largely avoid/revert decrease of cooked sorghum protein digestibility when applied before/after cooking. LWT-Food Sci. Technol. 2011, 4, 1245-1249. [CrossRef]

205. Noreña, C.P.Z.; Lescano-Anadón, C.E. Dielectric properties of importance in operations of post-harvest of sorghum. Int. J. Food Eng. 2017, 13, 20160369. [CrossRef]

206. Audu, J.; Ijabo, O.J.; Awulu, J.O. Influence of moisture and current frequency on electrical potential of sorghum grains (Sorghum bicolour (1.) Moench). Hungarian. Agric. Eng. 2018, 33, 24-29. [CrossRef]

207. Lohani, U.C.; Muthukumarappan, K. Application of the pulsed electric field to release bound phenolics in sorghum flour and apple pomace. Innov. Food Sci. Emerg. Technol. 2016, 35, 29-35. [CrossRef] 
208. Corey, M. Developing functional food products through novel processing, ingredient, and shelf stability evaluation. Ph.D. Thesis, University of Georgia, Athens, GA, USA, 2009.

209. Khan, M.K.; Ahmad, K.; Hassan, S.; Imran, M.; Ahmad, N.; Xu, C. Effect of novel technologies on polyphenols during food processing. Innov. Food Sci. Emerg. Technol. 2018, 45, 361-381. [CrossRef]

(C) 2020 by the author. Licensee MDPI, Basel, Switzerland. This article is an open access article distributed under the terms and conditions of the Creative Commons Attribution (CC BY) license (http://creativecommons.org/licenses/by/4.0/). 